(1) norden

Plastic value chains: Case: WEEE (Waste Electrical and Electronic Equipment)

Part 2 Report

111
THE NORDIC REGION
- leading in green growth 

2 norden 



\title{
Plastic value chains: Case: WEEE (Waste Electrical and Electronic Equipment)
}

\author{
Part 2 Report
}

John Baxter, Margareta Wahlstrom, Malin Zu Castell-Rüdenhausen and Anna Fråne 
Plastic value chains: Case: WEEE (Waste Electrical and Electronic Equipment)

Part 2 Report

John Baxter, Margareta Wahlstrom, Malin Zu Castell-Rüdenhausen and Anna Fråne

ISBN 978-92-893-3994-0 (PRINT)

ISBN 978-92-893-3996-4 (PDF)

ISBN 978-92-893-3995-7 (EPUB)

http://dx.doi.org/10.6027/TN2015-510

TemaNord 2015:510

ISSN 0908-6692

(C) Nordic Council of Ministers 2014

Layout: Hanne Lebech

Cover photo: Signelements

Print: Rosendahls-Schultz Grafisk

Printed in Denmark

This publication has been published with financial support by the Nordic Council of Ministers. However, the contents of this publication do not necessarily reflect the views, policies or recommendations of the Nordic Council of Ministers.

\section{www.norden.org/en/publications}

\section{Nordic co-operation}

Nordic co-operation is one of the world's most extensive forms of regional collaboration, involving Denmark, Finland, Iceland, Norway, Sweden, and the Faroe Islands, Greenland, and Åland.

Nordic co-operation has firm traditions in politics, the economy, and culture. It plays an important role in European and international collaboration, and aims at creating a strong Nordic community in a strong Europe.

Nordic co-operation seeks to safeguard Nordic and regional interests and principles in the global community. Common Nordic values help the region solidify its position as one of the world's most innovative and competitive.

\section{Nordic Council of Ministers}

Ved Stranden 18

DK-1061 Copenhagen K

Phone (+45) 33960200

\section{www.norden.org}




\section{Content}

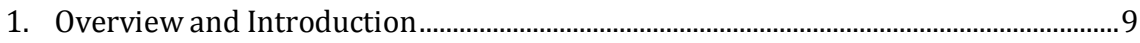

2. Enhancing plastics recycling - overcoming barriers and directing waste.............. 11

2.1 Introduction......................................................................................................... 11

2.2 Overall scale of the problem........................................................................... 11

2.3 Diversionary pathways for WEEE and plastics................................................ 14

2.4 Conclusions and recommendations................................................................... 17

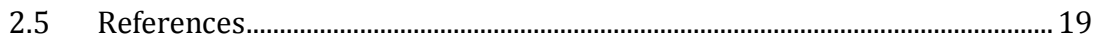

3. Traceability of waste through the value chain .............................................................. 21

3.1 Importance of traceability for WEEE plastic .................................................. 21

3.2 WEEE plastic traceability in the Nordic region ............................................ 22

3.3 Simple traceability schemes ........................................................................... 23



3.5 Smart labels and use of Information and Communication

Technologies (ICT) ....................................................................................... 25

3.6 Possible improvements for increased traceability of WEEE plastics

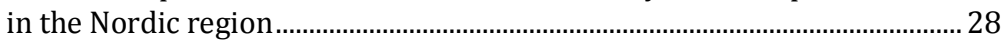

$3.7 \quad$ References....................................................................................................... 29

4. Technology-related issues in WEEE Plastics Recycling .............................................. 31

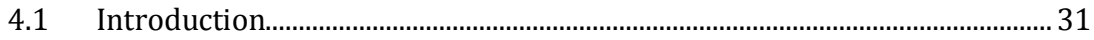

4.2 Initial disassembly of WEEE ............................................................................. 32

4.3 Separating the major plastics streams............................................................ 33

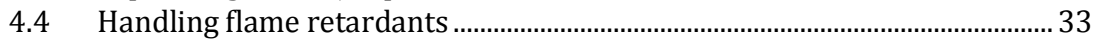

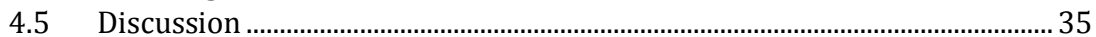

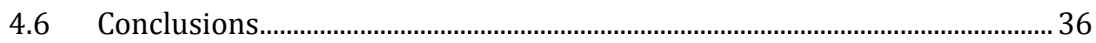

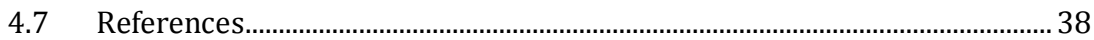

5. Environmental Declarations for Small Consumer Electronics: The Effect of

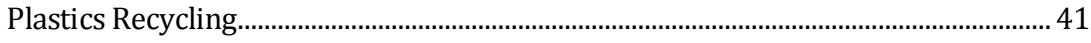

5.1 Introduction........................................................................................................ 41



5.2 Existing EPDs for Consumer Electronics......................................................... 43

5.3 EPD calculations for electronic products....................................................... 44

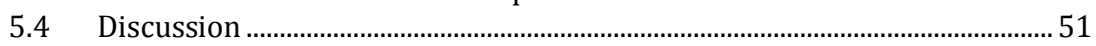

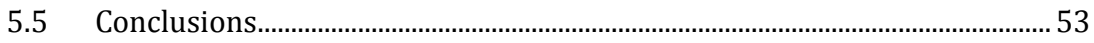

5.6 References............................................................................................................ 54

6. Extended Producer Responsibility Schemes...............................................................5

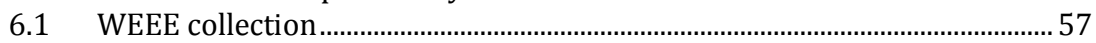

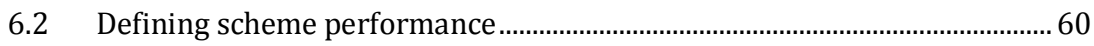

6.3 Areas of improvement to increase collection of WEEE plastics .................... 61

6.4 Possible improvements for collection and recycling of higher

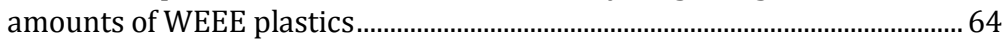

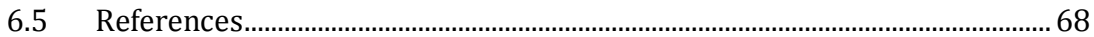


7. Discussion, Conclusions and Recommendations ......................................................... 71

7.1 Overall findings of the study .................................................................... 71

7.2 Summary of key findings from theme investigations................................... 72

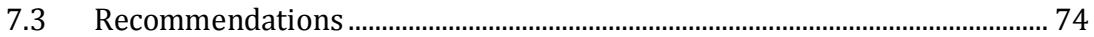

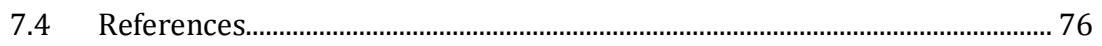

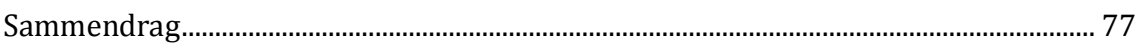

Annex A: An Illustrated Guide to Good Practice in WEEE Plastics Recycling................ 79 


\section{Summary}

This report is the primary outcome from Part II of the project "Nordic plastic value chains, Case WEEE (Waste Electrical and Electronic Equipment)" initiated by the Nordic Waste Group (NAG). It is accompanied by an illustrated guide to good practice for WEEE plastics recycling, given as Annex A.

The report builds on the findings of Part 1 of the project, which indicated that whilst recycling of WEEE in general is world-leading in the Nordic region, there is considerable room for further improvement in the recycling of plastics. Market and economic factors, rather than technical ones, were identified as being most important.

Improving WEEE plastics recycling is a responsibility shared along the value chain. A range of different themes, primarily addressed at different stakeholders, are addressed. The report finds that whilst the WEEE value chain is relatively effective for WEEE as a whole, it does not perform nearly as well for plastics. Resolving the technical and economic barriers to plastics recycling will involve some additional costs - but such additional investment would bring very wide-ranging advantages. Almost all of the current shortcomings of WEEE plastics recycling - including the diversion of wastes outside official value chains, and concerns regarding quality and hazardous materials - can be substantially reduced through a higher-quality, with somewhat higher cost, treatment and processing regime than is currently typical.

The report is part of the Nordic Prime Minister's green growth initiative: "The Nordic Region - leading in green growth". Read more in the web magazine "Green Growth the Nordic Way" at www.nordicway.org or at www.norden.org/greengrowth. 



\section{Overview and Introduction}

This report presents the results of Part II of the Nordic project: "Nordic plastic value chains Case WEEE (Waste Electrical and Electronic Equipment)."

The project is part of the Nordic Prime Minister's green growth initiative, "The Nordic Region - leading in green growth." The initiative identifies eight priorities aimed at greening the Nordic economies, one of which is to develop innovative technologies and methods for waste treatment.

To realise the Prime Minister's vision, the Nordic Waste Group (NWG) launched an initiative titled "Resource Efficient Recycling of Plastic and Textile Waste," comprising of six projects aimed at identifying ways in which the reuse and recycling of plastic and textile waste can be in-creased. Three of them, including the subject of this report, concern improved recycling of plastic waste.

The aim of this project is to provide an overview of the WEEE plastic waste situation in the Nordic countries, with a view to proposing improvements along the value chain. This forms part of the Green Growth initiative of the Nordic Council of Ministers, via the working group NAG (The Nordic Waste Group). It is one of three plastics recycling projects within the Waste part of that Initiative.

The overall aims of the project are to:

- identify, document and analyse existing practice for plastics in WEEE (Waste Electrical and Electronic Ecuipment)

- assess relevant legal, regulatory, economic and practical drivers for effective recycling of WEEE plastics

- suggest practical measures that might serve to develop and improve practice.

This report concentrates principally on the last of these. Based on a panNordic assessment of the situation in Part I of the project, five themes were identified as potential areas for improvement in practice. These are: 
- The reporting and administration of the WEEE plastics value chain.

- Traceability of waste through the value chain.

- Technologies for mechanical recycling of WEEE plastics.

- Incentives for producers via enhanced environmental performance.

- The structure of Extended Producer Responsibility schemes and related practice.

The main body of the work consists of five essentially self-contained reports addressing the above themes. General conclusions are drawn and the main findings are summarised in a user-friendly guide to good practice in WEEE plastics recycling.

The main target groups for the proposed results are policy makers and stakeholders in the Nordic countries, such as national and local authorities, relevant non-governmental organisations, private and public waste operators, trade and business organisations and the broader public.

The project is a collaborative effort between partners based in Norway, Sweden, Denmark, Finland and Iceland. 


\section{Enhancing plastics recycling - overcoming barriers and directing waste}

\subsection{Introduction}

Two of the opportunities for improvement in WEEE plastics recycling identified in Part 1 of the project (Norden, 2014) concerned "better understanding the scale of the problem" and "develop(ing) and share(ing) better understanding of the value chain."

More generally, Part 1 identified scope for considerably more WEEE plastics recycling than is currently identified. However, the scope was only identified in fairly broad, overall terms - and there is considerable potential for more detailed understanding.

The issue was, in part, identified via anomalies in the reporting and accounting of WEEE plastics. Specific discrepancies in data in official reporting frameworks such as Eurostat were identified, as discussed in Part 1. It emerges that reporting issues cannot be divorced entirely from other aspects of the value chain, and the actions of specific actors (including end consumers) have a strong bearing on the issue as a whole.

This Chapter primarily concerns barriers to waste entering the official WEEE (plastics) value chain. It has some significant overlaps with Chapter 6 concerning Extended Producer Responsibility schemes, and is effectively a precursor to the issues identified in Chapters 3-5 concerning traceability, recycling technology and environmental issues. As will be shown in this Chapter, unless and until waste enters the official value chain, the other issues become irrelevant - not least because there is essentially nil plastics recycling outside the official value chain.

\subsection{Overall scale of the problem}

The entry of WEEE (plastics) into the recycling value chain is governed in the first instance by EU targets for the collection and recycling of WEEE. The EU controls the fulfilling of these targets through mandatory 
national reporting. EU member states must assign a supervising authority, which is responsible for the reporting of WEEE management to the European Commission. The follow-up data includes volumes of EE put on the market, collected WEEE volumes including reuse and treatment.

Potential shortcomings in the reporting and accounting of WEEE and plastics were explored in Part 1 of the project (Norden, 2014). Whilst the main issues are relevant across all territories to some degree, specific issues were identified in Finland in particular. Finland's supervising authority is Pirkanmaan ELY-keskus (PirELY; the Pirkanmaa Centre for Economic Development, Transport and the Environment). PirELY collects statistics on the collection and treatment of WEEE and sends the report to the European Commission (this info is used in Eurostat). All producers are obliged to report to PirELY of all EE put on the market, an estimate of the generated WEEE divided among the 10 categories, collected WEEE of different categories, as well as volumes of WEEE that has been reused, recycled, recovered as energy or disposed; as well as where the treatment has taken place (domestic, within EU or outside EU). (VNA 852/2004).

The producer responsibility covers all producers and importers of EEE. The producers must either join a producer responsibility organisation, which takes care of collection, treatment and reporting to PirELY, or take care of these themselves. In Finland the "official" treatment system is the one of the producer's. All other collection and treatment is not reported and will not end up in the statistics. According to the new waste law only the producers are entitled to manage WEEE, hopefully increasing cooperation between the "unofficial system" and the producers, thus increasing the reported WEEE volumes. The follow-up data reported to the EC by PirELY includes only data provided by the producer organisations and self-compliant producers, excluding a significant part of the WEEE stream (Toppila, 2011).

Within EU goods are allowed to move freely, making the national reporting of EE complicated. EE imported from and exported to other EU countries are not reported, as are commonly not items bought online. For Norway, which is not an EU member country, detailed statistics on the EEE put on the markets is available. Most of the imported and exported EEE products are reported to the customs and included in the statistics. (Toppila, 2011).

The generated WEEE volumes are hard to estimate as a significant part of the generated WEEE is not collected by the "official system", and thus not reported to the authorities. Huisman (2007) estimates that in the EU-15 countries the annually generated WEEE volumes are approx. 17-20 kg per person. The reported WEEE volumes differ significantly 
depending on the reporting system. In Finland and Sweden only the WEEE collected by the EPR system is reported, leaving significant parts of properly treated WEEE outside the statistics. In Sweden, the reporting system enables double reporting for material being sent from one treatment facility to another (Hemström et al., 2012). From October 2014, the Swedish implementation of the WEEE Directive (Sveriges Riksdag, 2014) should result in tightening of reporting and data collection requirements. In Norway, the WEEE EPR scheme coverage is wider than in other territories (covering more fractions than the categories of the WEEE directive [2002/96/EC]), perhaps explaining why the generated and treated WEEE volumes are larger (Toppila, 2011). The reported collection and treatment rates for the Nordic countries are illustrated in Table 1.

\begin{tabular}{lrrrrr}
\hline Table 1: Overall Nordic WEEE statistics, $\mathbf{2 0 1 0}$ & & \\
\hline Territory & $\begin{array}{r}\text { Products put on } \\
\text { the market } \\
\text { (tonnes) }\end{array}$ & $\begin{array}{r}\text { Total WEEE } \\
\text { collected } \\
\text { (tonnes) }\end{array}$ & $\begin{array}{r}\text { Total WEEE } \\
\text { collected } \\
\text { (kg, per capita) }\end{array}$ & $\begin{array}{r}\text { WEEE treated } \\
\text { in home } \\
\text { territory or EU } \\
\text { state (\%) }\end{array}$ & $\begin{array}{r}\text { WEEE treated } \\
\text { outside the } \\
\text { EU (\%) }\end{array}$ \\
Sweden & 228,870 & 159,471 & 17.1 & $99.5 \%$ & $0.0 \%$ \\
Norway & 178,483 & 106,834 & 22.0 & $87.6 \%$ & $11.3 \%$ \\
Denmark & 145,959 & 82,237 & 14.9 & $98.6 \%$ & $0.0 \%$ \\
Finland & 145,639 & 50,023 & 9.3 & $99.4 \%$ & $0.2 \%$ \\
Iceland & 7,075 & 1,589 & 5.0 & $97.4 \%$ & $0.0 \%$ \\
\hline
\end{tabular}

Data source: Eurostat.

Table 1: from report 1

Although the generated WEEE volumes are hard to estimate, the volumes should be similar for the Nordic countries (e.g. Huisman, 2007; Toppila, 2011). Thus, the WEEE can be assumed to move along other paths than the official collection systems in all Nordic countries. According to the European WEEE Forum, the EPR systems cannot currently achieve $100 \%$ collection rates (Ongondo et al., 2011).

As reported in Part 1, in certain Nordic territories - notably Finland - the material flow of the unofficial system is significantly higher than in many other European countries, with only $50-60 \%$ of the WEEE being collected by the official system (Toppila, 2011). But the situation is not in any sense exceptional. According to Janz \& Bilitewski (2009) the German situation is similar, where the official system collects only approx. 50-63\% of the WEEE. In Holland only $30 \%$ of the WEEE is collected by the official system (Zonneweld, 2008). According to Bossi \& Carpentier (2011) as much as $50 \%$ of the WEEE in EU ends up in the unofficial collection systems, with an unknown destination and treatment. 
According to Ignatius et al. (2009), Hemström et al. (2012), and Chancerel (2009) much business-to-business WEEE is collected simultaneously and under the same contracts as other waste - by legal waste management companies and treated correctly, but not ending up in the official statistics. Furthermore, WEEE collected by the official system may end up in the unofficial system through illegal activities, such as theft and selling to third parties (Chancerel, 2010). However, this seems to be less common in the Nordic countries than on EU level (Toppila, 2009; Hemström et al., 2012)

\subsection{Diversionary pathways for WEEE and plastics}

The WEEE moves along several paths, making it hard for the official system to collect the waste. Besides the producers taking care of their EPR obligations, waste management companies collect WEEE for treatment, metal scrap handlers and other players are interested in certain fractions of the WEEE, a part of the stream ends up in the residual waste flow and some is stored in households. Among these players there are as well legal activities as illegal. (Toppila, 2011). This section addresses these pathways in turn.

\subsubsection{Legal and illegal recycling outside the EPR scheme}

Some of the fractions of the WEEE have a net positive material value, which is why it attracts several outside players. Some of the WEEE items may contain up to $50 \mathrm{w}-\%$ of metals (e.g. ovens) and other contains small, but valuable amounts of gold (circuit boards). Metal scrap dealers, both legal and illegal are actively involved in the collection of WEEE category 1 (large household appliances). Part of them because they do not see these as WEEE, but regular scrap metal, and part of them are aware of the regulation, but the financial drivers are too tempting. (Toppila, 2011). All over Europe it has become a problem for the official system to collect these fractions as scrap dealers often offer payment for these fractions (Zonneveld, 2008). According to Zonneveld (2008), the collection rates of this category is linked to the global metal prices; as metal prices rise, the collection rates of the official system is reduced.

Across the Nordic region there are numerous companies specialised in the collection of IT devices and mobile phones (category 3), and their services are becoming more and more popular. There are companies offering to purchase the old equipment of private people, and companies 
taking care of old leasing equipment. The share of collected IT and telecommunications equipment is significant, but they are not reporting collected volumes (at least not in Finland). A feature of several companies collecting specific WEEE items is that they attract customers by offering payment and easy-to-use recycling services. Instead of having to take your used mobile phone to a recycling centre yourself, you can e.g. order a pre-paid envelope online and send your phone to the recycler and earn some money at the same time. The majority of these companies are legal, offering collection, secure information destruction and recycling services. However, some are involved in illegal activities, selling the equipment for reuse instead of recycling the materials. Especially in this WEEE category, significant parts of the WEEE is illegally sold abroad for reuse and recycling, thus avoiding treatment costs and receiving income from the items suitable for reuse. (Toppila, 2011)

\subsubsection{Illegal exports including "used EEE"}

Note that this section refers primarily to (W)EEE rather than the plastics specifically. Issues concerning the export of separated plastics were already addressed in Part 1.

From EU countries significant volumes of WEEE is exported to developing countries labelled as used EEE, thus avoiding international waste transfer legislation (Saarinen 2011). Neither in Sweden (Hemström et al., 2012) nor in Finland (Härri, 2013) is there any difference in labelling between used and new EEE. However, according to several studies, the majority of these items are broken (EIA 2011, Saarinen 2011). It is also common not to report WEEE transfers at all, or to mix the WEEE with other shipments, such as used vehicles (Bossi \& Carpenter, 2011; Härri, 2013).

Data for a single destination for "used EEE" provides an indication of the issues. According to the Secretariat of the Basel Convention, SBC (2011), around 70\% of the EEE imported to Ghana in 2009 was used, of which around $30 \%$ was broken and should have been labelled WEEE. The total volume of irreparable EEE shipped to Ghana in 2009 was 40,000 tonnes (equal to $10 \%$ of the WEEE collected by the official systems in the Nordic countries in 2010). Härri (2013) has mapped several studies on EEE and WEEE shipments and concludes that approx. $25-75 \%$ of the used EEE shipped to emerging economies is not reusable.

Hundreds of thousands of tonnes of WEEE is annually exported from Western countries to emerging economies in Africa and Asia (Härri, 2013). The export is mostly illegal and therefore not reported in any statistic, which makes it very hard to estimate exported WEEE volumes. In 
the EU only 3.4 million tonnes of WEEE was collected through the official system in 2008; compared to 10.2 million tonnes of EEE prod-ucts entering the markets (EEA, 2012). EEA (2012) estimates that as much as 550,000-1.3 million tonnes of WEEE is annually exported, corresponding to as much as $5-13 \%$ of the annually generated WEEE. The EU is a significant exporter of WEEE; in a study it was revealed that up to $75 \%$ of the EEE/WEEE imported to Nigeria originated from the EU (SBC, 2011)

In emerging economies the treatment of WEEE is commonly done as "backyard treatment" using improper equipment and technologies and only recovering the most valuable materials. The most common technique is open flame burning; also leaching of printed circuit boards is common. Residues are commonly dumped in the environment and neither method recovers any plastics. (Härri, 2013)

\subsubsection{Diversionary routes related to the end-consumer}

A significant amount of WEEE is directed away from the official collection system as a result of consumer behaviour; the waste holder finds it easier to arrange for waste management through other routes than the official collection system (Chanceral et al. 2010). Households can sell their waste to several companies offering payment for IT devices and mobile phones, or they can discard them (illegally) with the household waste (YTV, 2007; Darby \& Obara, 2005).

Whether the WEEE ends up in the official collection system can be seen as dependent on the achievability and user friendliness of the collection system; if the official system is seen as too complicated or unreachable, the waste holder will find another way to discard of the WEEE (Darby \& Obara, 2005). The most used route is to discard of small WEEE with the residual household waste; only approx. $20-30 \%$ of the small WEEE ends up in the official collection system (Huisman et al., 2007). According to Darby and Obara (2005) the main reason for the small WEEE ending up in the residual waste is that people do not perceive these items as WEEE, and that people do not want to go to the trouble of taking the small WEEE to the collection points.

According to residual waste studies, the most common WEEE items found in the residual household waste is toys, leisure equipment, small domestic appliances and energy lamps (Toppila, 2011). In the residual household waste of the Helsinki Region in 2012, approx. $1.5 \mathrm{~kg} /$ cap is WEEE (YTV, 2013); in Sweden this amount is between $0.7-1.3 \mathrm{~kg} / \mathrm{cap}$ (Avfall Sverige, 2008, 2011); in Denmark < $1 \mathrm{~kg} / \mathrm{cap}$ and Iceland $1.8 \mathrm{~kg} / \mathrm{cap}$ (Table 5 in Chapter 6.3.3) and in Norway approx. $1.4-1.8 \mathrm{~kg} / \mathrm{cap}$ and falling (ROAF, 
2010 \& 2012). The share of WEEE ending up in the residual waste may seem small in comparison to the residual waste volumes, but the total volume is quite high. Based on the population of Finland in $2012(5,426,674)$ the total WEEE volume discarded in the residual waste was 8,140 tonnes of WEEE, this would make up for $16 \%$ of the volume collected by the official system in 2010. The respective number for Sweden is 6,000-12,000 tonnes of WEEE (3.7-7.5\%), for Denmark it is about 2,900 tonnes, for Iceland 580 tonnes and for Norway 7,000-9,000 tonnes (6.5-8.4\%). Notable is, that the small WEEE that is discarded with the residual waste have a low weight and small size, making the total number of items ending up in the residual waste very high.

Another significant bottleneck for the efficient collection of WEEE is consumer hoarding. Darby \& Obara has studied several European studies on WEEE management and common for all is that people tend to store significant volumes of EEE and WEEE at their homes instead of delivering it to collection. The more valuable an item is, the more likely for its owner to keep it after use. (Darby \& Obara, 2005). A Swedish study showed that households have at least 10 million mobile phones in storage, a common situation in all Nordic countries (Malmström, 2011). A study by Nokia shows that $75 \%$ of mobile phone users would not consider recycling an old functioning phone when purchasing a new one. Only $4 \%$ of mobile phone users recycles their old phones; $60 \%$ keep the phone themselves and $20 \%$ gives it to someone else, but only $1 \%$ admits to discarding the phone in the residual waste. (Digi Today, 2008).

\subsection{Conclusions and recommendations}

In general, opposite to what reported numbers may indicate, it seems as the majority of WEEE is recycled properly in the Nordic countries, although the treatment routes vary. The main routes for uncontrolled treatment are hoarding, discarding in residual waste and export. None of the unofficial WEEE recycling routes offers any prospects for plastics recycling. Legal or illegal diversion of waste outside official channels (be it domestic or international), consumer stockpiling or discarding in residual waste - in none of these cases are plastics recycled significantly, if at all.

Recommendations for improvements must therefore focus on directing material along official channels - or, equivalently, limiting the diversion of WEEE away from these channels. In many cases the findings of this Chapter serve to introduce issues explored more deeply elsewhere 
in this document. Recommendations that can be considered unique to this Chapter are shown below in bold.

- The greatest threat to the recycling system is the illegal export of WEEE and used EEE. Reuse of IT and telecommunications equipment can cause serious information security issues, and proper recycling technology cannot be guaranteed in third world countries. WEEE is exported illegally from all Nordic countries. EEA (2012) estimates a $5-13 \%$ export of WEEE from the EU of generated (not collected) volumes, compatible with the officially declared Norwegian WEEE export. A bold assumption would be to suppose the actual Nordic export for all countries is at or around this level. Better policing of waste exports is clearly needed and would probably be the single most important factor for keeping waste in the system.

- As reported above, WEEE is often (dubiously) shipped as used EEE. Apart from the obvious direct effects of this, there is an important secondary effect. Exported EEE is subtracted from the volumes put on the market (Hemström et al., 2012). Thus, the effective volume of items put on market - and hence the amount of waste that must be collected and treated under Extended Producer Responsibility - is actually reduced by illegal WEEE exports. ${ }^{1}$ The relevant regulations for classifying (used) EEE and WEEE need careful examination and probable tightening.

- The main problem with reporting seems to be the lack of legal obligations to report collection and treatment of WEEE rather than the actual collection rates. In both Sweden and Finland collection routes have been identified where waste management companies with sufficient permits can collect WEEE and deliver it to proper treatment without being obliged to report volumes to authorities (Toppila, 2011; Hemström, 2012). The solution may be based in more discerning regulatory targets, which is discussed further in Chapter 4.

- Keeping waste in the system instead of the legal (e.g. scrap metal) recycling system is primarily a matter of economics. Essentially there must be higher value associated with waste in the system - via the fees payable for its processing and recycling - than is currently the case. This is explored in much more detail in Chapter 4.

\footnotetext{
1 This will be the case from 2016, when collection targets under the WEEE Directive are related to the volume of waste put on the market.
} 
- Discarding is mainly a problem for small WEEE, mainly consisting of plastic and which people may not regard as WEEE. These items do not cause much direct harm to the environment if incinerated or landfilled and they commonly do not contain significant volumes of valuable materials. Nonetheless the indirect effects of failing to recycle, specifically the missed opportunities to avoid virgin (plastic) material production, are considerable - this is explored further in Chapter 5. Educating the consumer is clearly a factor here - this is explored in Chapter 6.

- The volumes of WEEE accumulating at people's homes are hard to measure, but similar Nordic cultures and consumer behaviour probably results in similar hoarding behaviour. Similar volumes per capita ending up in the residual waste probably means that WEEE sorting is at the same level in all Nordic countries. As for residual waste discarding, consumer education is important - see Chapter 6.

\subsection{References}

Avfall Sverige. (2008). Vart tar smått elavfall från hushåll vägen? Studie av plockanalyser samt hushållens attityder och agerande. Rapport 2008:03, ISSN 1103-4092.

Avfall Sverige. (2011). Nationell kartläggning av plockanalyser av hushållens kärl- och säckavfall. Aktuella resultat och metodik. Rapport U2011:4, ISSN 1103-4092.

Bossi, T. \& A. Carpenter. (2011). Resource Efficiency: How to improve recovery rates of valuable raw materials. International Platinum Group Metals Association (IPA). [19.6.2014] http://www.ipa-news.com/en/files/ipa_newsletter_spring_2011.pdf

Chancerel, P. (2010). Substance flow analysis of the recycling of small waste electrical and electronic equipment: An assessment of the recovery of gold and palladium. Technische Universität Berlin, Doctoral Dissertation. http://opus4.kobv.de/ opus4-tuberlin/files/2463/chancerel_perrine.pdf

Darby, L. \& L. Obara. (2005). Household recycling behavior and attitudes towards the disposal of small electrical and electronic equipment. Journal of resources conservation \& recycling 44, 17-35. http://dx.doi.org/10.1016/j.resconrec.2004.09.002

Digi Today. (2008). Nokia: Vanhat puhelimet jäävät nurkkiin lojumaan. [19.6.2014] http://www.digitoday.fi/mobiili/2008/07/08/nokia-vanhat-puhelimet-jaavatnurkkiin-lojumaan/200817955/66

European Environment Agency, EEA (2012). Movements of waste across the EU'S internal and external borders. EEA Report. 7/2012.

Härri, A. (2013). Kaukainen kaatopaikka. E-jätteen matka Suomesta kehitysmaihin. [28.11.2014] http://www.eetti.fi/sites/default/files/E_jate03FINAL_net_0.pdf

Hemström, K., Å. Stenmark, L. Sörme \& A. Carlsson. (2012). Kartläggning av flöden och upplagrade mängder av elektriska och elektroniska produkter i Sverige 2010. SMED rapport Nr. 105 2012. [19.6.2014] http://eeb.naturvardsverket.se/Global/ Rapporter/SMED-Rapport-2012-1024.pdf 
HSY, Helsinki Region Environmental Services Authority. (2013). Pääkaupunkiseudun kotitalouksien sekajätteen määrä ja laatu vuonna 2012. Helsinki: HSY publications 2/2013. [19.6.2014] http://www.hsy.fi/tietoahsy/Documents/Julkaisut/ 2_2013_pks_kotitalouksien_sekajatteen_maaja_ja_laatu_lr.pdf

Huisman, J., Magalini, F., Kuehr, R., Maurer, C. (2007). 2008 Review of Directive 2002/96 on Waste Electrical and Electronic equipment. Final report. United Nations University Study No. 07010401/2006/442493/ETU/G4. [19.6.2014] http://ec.europa.eu/environment/waste/weee/pdf/final_rep_unu.pdf

Ignatius, S-M., Myllymaa, T., Dahlbo, H. (2009). Sähkö-ja elektroniikkaromun käsittely Suomessa. Helsinki: Suomen ympäristökeskus. Suomen ympäristökeskuksen raportteja 20/2009. [19.6.2014] https://helda.helsinki.fi/bitstream/handle/ 10138/39678/SYKEra_20_2009.pdf?sequence=1

Janz, A. \& B. Bilitewski. (2009). WEEE in and outside Europe- hazards, challenges and limits. Lechner, P. (ed.) Prosperity Waste and Waste Resources. Proceedings of the 3rd BOKU Waste Conference. April 15-17. [19.6.2014] http://wasteonference.boku.ac.at/downloads/publications/2009/presentations/2-1_Janz.pdf

Malmström, P. (2011). Kännykät pöytälaatikoista kiertoon. Uusiouutiset 2/2011, 32. Finnish Recycling News professional magazine. [19.6.2014] http://www.uusiouutiset.fi /wp-content/uploads/2011/03/uu20112_s32.pdf

Norden. (2014). Plastic Value Chains, Case WEEE (Waste Electrical and Electronic Equipment) in the Nordic Region, http://www.norden.org/no/publikasjoner/ publikasjoner/2014-542 (accessed November 2014) http://dx.doi.org/10.6027/TN2014-542

Ongondo, F.O., I.D. Williams \& T.J. Cherrett. (2011). How are WEEE doing?: A Global Review of the Management of Electrical and Electronic Wastes. Journal of Waste Management 31 (4), 714-730. http://dx.doi.org/10.1016/j.wasman.2010.10.023

ROAF. (2010). Plukkanalyse restavfall 2010. Analyse av restavfall fra hente- og bringeordninger. [19.6.2014] http://roaf.custompublish.com/getfile.php/ 2092960.1919.xvcrbqfxfu/ROAF_Rapport_Plukkanlayse_2010.pdf

ROAF. (2012). Plukkanalyse restavfall 2012 - Husholdninger - Gjenvinningsstasjoner. [19.6.2014] http://roaf.custompublish.com/getfile.php/2353620.1919.uxqrvvybuf/ Plukkanalyse+2012.pdf

Saarinen, E. (2011). Valvojat rikollisten jäteviejien kannoilla. Uusiouutiset 2/2011. Finnish Recycling News professional magazine.

Secretariat of the Basel Convention, SBC (2011). Where are WEee in Africa? Findings from the Basel Convention E-waste Africa Programme.

Sveriges Riksdag. (2014). Förordning (2014:1075) om producentansvar för elutrustning, http://www.riksdagen.se/sv/Dokument-Lagar/Lagar/Svenskforfattningssamling/ Forordning-20141075-om-prod_sfs-2014-1075/?bet=2014:1075

Toppila, A. (2011). Jätehuollon tuottajavastuun jätevirrat. Esimerkkinä Sähkö- ja elektroniikkalaitteet sekä kannettavat paristot ja akut. Master's thesis, University of Jyväskylä.

Zonneweld, N. (2008). Why do we need change? European Electronics Recycling Association (EERA). 4th Annual Conference: Electrical and Electronic Waste, 1-2.10.2008, Brussels. 


\section{Traceability of waste through the value chain}

The literature shows a huge body of statistics and data on WEEE and plastics, both across the Nordic region and more generally across Europe. Invariably, different sources often contain slightly different information from different perspectives, using different definitions and assumptions, and establishing a coherent, reliable picture is rarely straightforward.

\subsection{Importance of traceability for WEEE plastic}

Despite the WEEE legislation on treatment and restrictions (such as e.g. RoHS), WEEE management suffers from lack of traceability. This meaning that it is difficult to link and keep track of input and output waste flows in WEEE management systems, and more in general is difficult to keep track of input and output material flows in the EEE-WEEE supply chain. This is reflected directly in the management of plastic WEEE. The drawback of this situation is that reporting becomes more complicated and imprecise, and that legal compliance is not guaranteed. Full traceability of WEEE plastic should allow to increase collection rates, reduce uncontrolled flows such as illegal shipping to developing countries, and to ensure proper treatment of the materials according to their plastic composition and content in hazardous substances. In fact, a better traceability of WEEE plastic at collection and sorting facilities facilitates as well the identification of plastic containing or not hazardous substances and the achievement of reuse, recycling and recovery targets. Traceability may be also a key issue considered the general and increasing trend towards producing smaller electronic devices (Binder et al., 2008). These are more likely not to be properly brought back to either stores or municipal WEEE collection stations, and instead end up in unsorted household waste and therefore in disposal facilities directly, such as incineration plants. In summary, reasons for increasing traceability are (WEEE TRACE, 2014): 
- Need to increase WEEE collection rates as required by new legislation.

- Guarantee WEEE is conveyed to the appropriate treatment plants.

- Minimize illegal exports or leaks to substandard treatment.

- Constitutes the basis for regulatory reporting.

- Allows optimising logistics.

- Improves waste processing on site.

\subsection{WEEE plastic traceability in the Nordic region}

What is known from previous interviewees (cf. part I of the project) is that the current WEEE management in the Nordic Region suffers from the lack of traceability.

Even though several companies can perform WEEE treatment within the Extended Producer Responsibility (EPR) schemes, not all of these reach the same efficiency and quality of sorting. The EPR schemes can influence sorting via tenders, and seem to have a substantial influence on this market, although the focus seems to be mostly on the prices of services and not on the quality of the final products. Thus, the improvement of traceability may be useless if not coupled with higher standards for quality of sorted output plastic materials. It is unclear whether this problem should be addressed via a more strict regulation of what recyclers can take plastic WEEE, via the use of certification, or left to the market actors to adapt according to prices and services provided.

The composition of WEEE Plastic is often unknown. Producers in the Nordic region are often importers; with no real control on the composition of the plastic materials they are using (being it virgin or recycled). Sorting facilities report serious problem in lack of knowledge about plastic composition and content in hazardous substances for plastic WEEE that should be addressed by increasing traceability of the plastic materials. This is a major problem for WEEE from households. For WEEE collected directly from producers, the problem can be limited by a closer communication between producers and recyclers. The same companies consider an improvement in traceability useful as would allow for better sorting; with direct market implication as high quality sorted materials can be sold at higher prices in the market for plastic recycling.

Last, traceability issue that is probably minor regarding quantities, but not regarding the relative environmental and social impact is the 
illegal shipping of electronic waste. These flows are by definition nontraceable and should be limited.

\subsection{Simple traceability schemes}

Traceability schemes exist for other types of waste and especially for hazardous waste and some pilot tests have been recently proposed performed for specific plastic fractions e.g. in the field of agrochemical plastic packaging waste (Briassoulis et al., 2014). The main features of a traceability scheme consist of tracking who delivers the waste, the type of waste, and the final destination after sorting or treatment. The entire system is based on labelling of the input/output products and the collectors and recyclers are supposed to be registered to the scheme. For WEEE plastics, the scheme should mirror and be integrated within the existing WEEE collection schemes that most of the Nordic countries analysed in the project have adopted. Main components of a simple traceability scheme should therefore be:

- Registers of authorized WEEE-plastic collectors and recyclers.

- Supervision of input material at the collection/recycling point.

- Labels on plastic allowing for traceability of the whole plastic chain.

- Sampling and hazardousness analysis of the plastic outputs (optimally at the sorting facility).

The supervision of material may vary in thoroughness. The key issue is verifying the authenticity of the material (i.e. the material is what it is supposed to be, e.g. plastic). A more advanced traceability scheme implies that materials are weighted at each exchange step and who delivers the material is also registered by the receiver. This may for example mean the pre-processing facility registering how much plastic waste each municipality has delivered.

On a larger perspective covering the entire supply chain, plastic producers and recyclers should be integrated in the scheme, e.g. allowing for a labelling of the recycled plastic reused into production processes. The expected advantages of such a scheme would be eliminating illegal WEEE plastic or mismanagement of WEEE plastic, enforcement of the relevant legislation, transparency through quantification of the WEEE plastic collected and recycled, and treating the plastic in appropriate facilities (recycling, incineration for mixed WEEE plastic RoHS compliant, and hazardous waste treatment for the rest) (Briassoulis et al., 2014). 


\subsection{Visual labels and symbols}

The use of labels is common in the traceability of hazardous waste and should be improved regarding WEEE and potentially introduced regarding WEEE plastic. The WEEE directive introduced a symbol for identifying WEEE from other waste (EP and EC, 2012) allowing for proper management of WEEE. However, this does not provide any information on plastic WEEE obviously. Several visual labels for product identification and environmental compliance already exist for WEEE plastic and RoHS materials, however it is unclear to what extend these are used. These seem to be mostly relevant for plastic producers outside EU who want to export their products to EU (whereas plastic produced within EU must be RoHS compliant). Besides, these are applied voluntarily. See examples in figure 1 below. The study of Ku et al. (2009) reports that in Korea consumers are requested to put stickers on their bulky waste, including televisions and refrigerators, when delivering it. Stickers are available at village offices and supermarkets. It is debatable whether this solution would be applicable to WEEE plastic since requires a detailed knowledge of the plastic composition by consumers, which is unlikely. It is instead more likely that producers could adopt labels or mark their plastic products with (additional) information regarding the composition. For example, these labels or laser marks should move beyond the traditional set of symbols of the SPI resin identification coding system instituted by the Society of the Plastics Industry (SPI). The SPI labels are useful for identifying the polymer type. Additional relevant information to be reported should be the compliance with RoHS, whether the material contains Brominated Flame Retardants (percentage), or the respective content in recycled and virgin materials. 
Figure 1: Examples of visual labels for product identification and environmental compliance

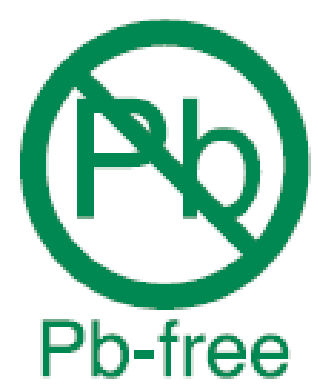

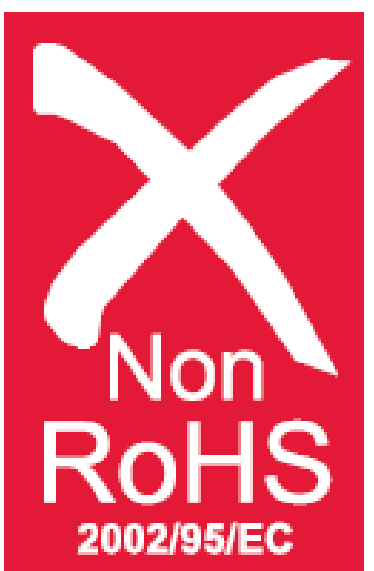

\subsection{Smart labels and use of Information and Communication Technologies (ICT)}

Smart labels range from barcodes to the more advanced Radio Frequency Identification Devices (RFID). This sort of technology has seen a rapid development in recent years, with several test performed on different kinds of goods (e.g. food) and with decreasing costs. Barcode label technology for waste tracking in basically similar to what supermarkets do for their grocery products (WRAP, 2009). Barcodes storing capacity varies according to different technical parameters (encoding type, error correction, shape, etc.): 1D barcodes can store a small amount of text and numbers (e.g. up to 30), whereas 2D codes can store larger text amount of text and numbers (e.g. up to 7,000). This means not only a label identifying an object, but also a text describing the object, and images (this could be something equivalent to e.g. $32 \mathrm{~KB}$ data). In general, however, there is a trade-off between amount of information stored and readability. RFIDs work in the same conceptual way but consist of three components: antenna, transceiver (with decoder), and transponder (RFtag) electronically programmed with unique information (Binder et al., 2008). The advantage of using RFIDs is that they essentially a tag that communicates directly to a reader without needing need physical contact or sight positioning. Therefore, they are more appropriate to applications in environmental unfavourable conditions (humidity, high temperature, light exposure etc.) and thus in the area of waste management (Gnoni et al., 2013). 
Using tracking references, the use of smart labels allows creating an individual waste record that is stored in a database and accessed when reading the tags. Although RFIDs have a limited storage capacity (comparable to 2D barcodes) that allows storing some key data, their key feature beside reading time and durability is that they can be used as unique identifiers for each object. The unique identifier can't be changed, but the data contained in the database can be edited (e.g. by adding or updating information) at different stages in the life-cycle of the object. This is not possible with barcodes unless a new barcode is printed. Thus, the amount of information that can be associated with the unique code of a RFID is substantial. For applications in the waste sector including WEEE and beyond (e.g. plastic for food packaging), the system can record a wide range of information including all critical regulatory details (Binder et al., 2008; WRAP, 2009), such as e.g.:

- waste producer name

- waste description, e.g. composition

- consignment Note Number

- collection date and time (proof of collection and delivery)

- on-site storage location and treatment date

- off-site shipping and disposal including where, when and how.

Given these features, general advantages of the use of smart labels are that make easier to split quickly the mixed waste fractions and to separate and store more efficiently the materials for treatment or recycling. Other reported advantages are: standardization of information, simplification of reporting, making the process of tracking waste movement less time-consuming, and increasing the confidence in waste accountancy (WEEE TRACE, 2014; WRAP, 2009).

The potential for application of smart labels for WEEE plastic is mostly unexplored. Theoretical applications of RFID were described by Binder et al. (2008) regarding electronic appliances, intended as waste from composite goods containing electronic elements. For the WEEE management sector, the most useful application of tagging would be targeted to sorting and separating waste materials and detecting recyclable from toxic components. In order to perform this, it is essential that information on the plastic composition is stored in the tags by the producers and most importantly is accessible after an EEE item is purchased until it becomes waste (WEEE). This aspect is likely to pose problems regarding privacy, as discussed below. However, the re-search of Binder 
et al. (2008) has showed that stakeholders (mostly recyclers) are in general positive regarding this solution as environ-mental protection is prioritized over privacy issues (Binder et al., 2008). At the preprocessing facility, the reading of labels should happen right after sorting the waste products by regulatory categories (i.e. the different WEEE categories), and right before the shredding phase.

The recent WEEE TRACE (2014) project is real-word applications of smart labels on WEEE used ICT such as radiofrequency tagging and image recognition to ensure cradle-to-grave traceability of WEEE flows. The project run pilot experiences in Spain and in the Czech Republic and its results were intended to be exportable to other European WEEE compliance schemes or to other waste streams with similar control and traceability requirements. Results of the WEEE TRACE project included Increase collection levels and "a reduction in treatment costs of waste fridges between 4 to $10 \mathrm{EUR} /$ unit as a result of increased collection volumes, improvements in logistics, better identification of treatment needs and minimization of administration compliance burden."

Reported disadvantages smart labels are the need for a system tailored for individual business needs (especially regarding barcodes for use at single facilities). Another disadvantage is that social acceptance may be limited for smart labels, both from consumers and producers. The former may be willing to protect their consumption habits, the latter may want to protect the knowledge about their product's design (in terms of materials used). Although this is a general issue for labels, in the case of smart labels one solution is storing the information on the WEEE plastic composition on a networked database and link this to the tag ID though an encrypted code. Information would be downloaded but only during the dismantling/sorting procedure. Binder (2008) considers this option likely to be appropriate for durable goods such as WEEE and should therefore fit the case of WEEE plastics. Further investigations should determine what level information is considered safe for both consumers and producers. Costs include capital costs of implementation, variable from business to business, and service costs (system maintenance and equipment supplies). A significant amount of training required for operators in sorting facilities was reported as an initial but easy to overcome problem both in case of barcode and RFID systems. 


\subsection{Possible improvements for increased traceability of WEEE plastics in the Nordic region}

The implementation of traceability schemes should be encouraged, within the existing EPR schemes. In order to achieve this:

- the registers of producers, importers, and recyclers should be updated. For pre-processing facilities, it should be considered the use of certification or a better focus on quality of the service (efficiency of sorting and quality of output flows) rather than on price. Transaction costs for implementing a certification system may be substantial, whereas an update of registers should be within the reach of EPR schemes

- close communication between producers and recyclers is a first step to increase traceability. This is already normal practice for some situations according to the information retrieved in part I, but could be improved via specific initiatives (roundtables, workshops, seminars, networking activities involving both producers and recyclers, surveys, etc.) of e.g. for the EPR schemes this would be feasible both in terms of organization and low costs

- producers who claim they are not sure about the composition of their plastics should perform extra analysis. The quality of the recycled plastic used in the products should be also ensured and traceable. However, and as revealed in Part I of the project, analysis are costly and performed only occasionally, so this practice will need some economic compromises

- when mixed plastics are shredded, then also the final composition of the sorted fractions may be unknown, it is beneficial to improve the characterization of this plastic and allow for tracing the final destination of these flows. Similar considerations as above regarding the high costs of chemical analysis 
Regarding the use of labels and smart labels:

- The use of ICT technologies and of smart labels may result beneficial for improving traceability of WEEE plastic. The increasing use of databases and cloud-based services is supposed to boost and ease their application in the future. Besides, seems like the technologies are increasingly affordable. The possibility of storing a good amount of information regarding the plastic composition and origin opens for several possibilities of improving sorting and recycling.

- Pilot studies of smart labelling system are recommended before upscaling. Previous pilot studies have focused on the waste management phase. These have looked both at specific items and to batches of products (e.g. televisions) and at which solutions allow for: the reading of codes easily and efficiently at waste pre-processing facility, how user friendly the technology is, and what information is needed and must be reported at this stage to improve the sorting process. Then, the optimal scale needed for the system should be identified, e.g. by testing whether a national system or international one would be more advantageous, and to which WEEE fractions this should be applied. Given the implementation costs, it may be reasonable to avoid small-enterprise systems and aim for national or Nordic area coverage. It is difficult to estimate the feasibility of such an initiative at EU scale, but it could be investigated.

- The technology is not free of drawbacks, the most serious being issues of privacy and of consumer acceptance. Even though these seem to be solvable with technological solutions, they should be thoroughly investigated prior to the application of smart labels on large scale. The use of online surveys may help abating the costs of such investigations.

\subsection{References}

Binder, C.R., Quirici, R., Domnitcheva, S., Stäubli, B. (2008). Smart Labels for Waste and Resource Management. Journal of Industrial Ecology 12, 207-228. http://dx.doi.org/10.1111/j.1530-9290.2008.00016.x

Briassoulis, D., Hiskakis, M., Karasali, H., Briassoulis, C. (2014). Design of a European agrochemical plastic packaging waste management scheme-Pilot implementation in Greece. Resources, Conservation and Recycling 87, 72-88. http://dx.doi.org/10.1016/j.resconrec.2014.03.013

EP, EC (2012). DIRECTIVE 2012/19/EU OF THE EUROPEAN PARLIAMENT AND OF THE COUNCIL of 4 July 2012 on waste electrical and electronic equipment (WEEE)Text with EEA relevance. 
Gnoni, M.G., Lettera, G., Rollo, A. (2013). A feasibility study of a RFID traceability system in municipal solid waste management. Int. J. Information Technology and Management 12, 9. http://dx.doi.org/10.1504/IJITM.2013.051632

Ku, S.-J., Yoo, S.-H., Kwak, S.-J. (2009). Willingness to Pay for Improving the Residential Waste Disposal System in Korea: A Choice Experiment Study. Environmental Management 44, 278-287. http://dx.doi.org/10.1007/s00267-009-9325-5

WEEE TRACE, (2014). Full Traceability of the management of WEEE (WEEE TRACE). WRAP (2009). Waste Logistics Case Study - Improving Waste Traceability and Control. WRAP - Waste \& Resources Action Program. 


\section{Technology-related issues in WEEE Plastics Recycling}

\subsection{Introduction}

This study concerns issues relating to technology in WEEE plastics recycling, and builds upon findings of Part 1 in the project. It concentrates on technologies and routines for the manual and/or mechanical sorting, separation and ultimately recycling of plastics in WEEE. Whilst consultation across the sector consistently reveals that technological issues are not at the forefront of considerations for most actors, they remain significant for the value chain as a whole. The study will highlight areas where technical practice in WEEE plastics recycling could be improved. As will be shown, "technical practice" implies more than the mere choice of technologies.

The study attempted to address the following broad issues (across the Nordic region, but also more generally):

- Identify the range of separation / recycling technologies currently available / in use.

- Assess the fitness for purpose of these technologies, identify shortcomings.

- Examine issues relating to flexibility and cost of technologies.

- Consider likely ongoing technological developments.

- Consider synergies with value chains for other waste sources (particularly plastic packaging).

There are essentially three stages in the recycling process for WEEE plastics:

- Disassembly of WEEE and the isolation of (mixed) polymer streams.

- Identification and sorting / separation of different polymer streams.

- Reforming separated polymers into usable raw materials / products. 
The last of these will not be addressed in this study; investigations indicate that once the polymer streams are identified and sorted, the (re-) formation of new materials and products involves highly standard procedures that are general manufacturing elements rather than being specific to recycling processes - including melting, sieving, re-granulation and injection moulding.

The second stage (identifying and separating polymers) is the obvious main focus. As is almost universal for the sector and for most research, the focus is on essentially mechanical rather than chemical methods for separation. The study reveals that, although the disassembly stage is itself very well understood and is fairly standard, it has significant effects on the process as a whole. The analysis here also assumes that the separation of plastics from other elements of WEEE, notably metals, proceeds fairly trivially. This was described briefly in Part 1 .

\subsection{Initial disassembly of WEEE}

In the initial treatment of WEEE, whilst manual disassembly and presorting remains fairly standard for certain product types (a notable example being LCD TVs), this is largely a matter of necessity - for example to ensure the removal of particularly hazardous materials such as mercury. The trend is very much towards increasingly mechanised and automated processes for disassembly, with increasingly complex processes being devised.

The analysis of Peeters et al. (2014) establishes a useful dichotomy of pre-treatment processes; Ardente et al. (2014) provide a fuller picture. Both analyses apply to flat screen electronic displays, although it seems the broad conclusions are more generalizable. The Peeters analysis gives two scenarios as follows:

- A "disassembly" scenario, which is essentially manual in nature. Plastics are manually separated from other WEEE elements and are also identified and separated manually, using a combination of techniques, including hand scanning using Fourier Transform Infrared Spectroscopy (FTIR).

- A "size-reduction" scenario which is based around conventional processes of shredding and screening followed by automated optical sorting and density-based separation processes. 
It emerges that the approach to initial disassembly is crucial for the overall performance of the separation process as a whole.

\subsection{Separating the major plastics streams}

Much of this has been covered in Part 1 of the report. For the most part, the technologies seem well-established and developed. As per Part 1, we essentially assume that the challenge is to separate a mixture of ABS, PS and PP containing small amounts of other plastics and potentially substantial amounts of (brominated) flame retardants (BFR). In general, three technologies are in use for these separations. All are fairly standard and widespread, the biggest issues in general being the high capital investment required to establish an economically sustainable facility, and the need for large, consistent throughputs to sustain this. Density separation is particularly suitable for removing the polyolefin plastics from the styrenics. Optical and/or electrostatic techniques may be needed for the more challenging separation of ABS from PS.

\subsection{Handling flame retardants}

As identified in Part 1 of the project, hazardous materials in WEEE plastics present a particular challenge. There are essentially two types of hazardous materials - heavy metals (lead, cadmium, mercury) and (brominated) flame retardants (BFR). Particularly for the small consumer electronics products in focus in this project - in Groups 2-4 in the WEEE directive - the latter have been identified as a particular issue. Here we will concentrate on the technological issues and challenges relating to separating BFRs from WEEE plastics streams.

As discussed in Part 1, the legislation relating to BFRs, specifically the RoHS Directive and the EU regulation on Persistent Organic Pollutants or POPs (850/2004) together place severe restrictions on the handling of (plastics containing) BFRs. The regulatory framework is complex but nonetheless the broad aim is to completely eliminate these substances over time. The substances of most relevance for WEEE are the polybrominated diphenyl ethers (PBDEs). Two of the three most common (penta-BDE and octa-BDE) have long been established as POPs, with the third (deca-BDE) in the process of being so classified.

Excluding the (illegal) "strategy" of exporting WEEE plastics containing flame retardants outside Europe, permanent destruction of the contami- 
nated plastics is the only realistic option. The key is to separate flame retardant plastics from others as thoroughly as possible thereby creating a non-recyclable plastics stream (not compliant with RoHS in terms of hazardous concentration) that is then subjected to incineration with energy recovery. There are obviously economic and environmental costs associated with the loss of any clean plastics that are carried with the contaminated fraction owing to the limited effectiveness of separation.

As mentioned above, the analysis of Peeters et al. (2014) establishes two possible pre-separation scenarios, with results that have profound implications for the effectiveness of separation. For the (conventional) size-reduction scenario in the Peeters analysis, separation efficiency is compromised by density overlaps between different fractions, and optical separation via NIR is compromised by substantial amounts of black plastics in the mix. In the specific study these were PC/ABS plastics containing phosphor flame retardants, but the general principles hold for brominated flame retardants also. The study focused on the potential recyclability of (non-POP) plastics but has identical implications of separation effectiveness for selective removal and destruction of flame retardant plastics.

Compromises in separation efficiency were found to affect both yields and purities in the separation process. The flame retardants are effectively eliminated, but a yield of only around $70 \%$ is achieved. This means that $30 \%$ by mass of the original plastic stream - the vast majority of which being "clean" - is lost (meaning sent for incineration). Furthermore, the recovered stream is only around $80 \%$ pure - meaning that the target plastic remains mixed with other (clean) parts of the stream.

In contrast, the disassembly scenario yielded much more effective separation, with potentially recyclable plastics in compliance with the RoHS requirements (meaning purities in excess of 99\%). The recyclable plastics showed a slight diminution in certain properties, but were deemed commercially viable with the possible exception of certain aesthetic factors.

The implications for brominated flame retardant separation do not relate to recyclability (which is not on the agenda because of POP status) but separation effectiveness more generally. To reiterate, these studies indicate that considerably more effective separation of flame retardant plastics from a mixed stream can be achieved through a disassembly process than a size separation one. 


\subsection{Discussion}

Whilst it may seem counter-intuitive to recommend the slowing of technological progress and automation, there is some evidence to indicate that a reversal, or at least slowing, of the current trends in WEEE treatment towards increasing mechanisation and automation, at ever earlier stages of the treatment value chain, may be desirable for a number of reasons. There is fairly clear evidence that the recycling of WEEE plastic materials can be considerably enhanced by reverting to a treatment chain based more around manual disassembly.

It may well emerge that additional regulatory drivers in terms of recycling performance, for example targets relating to the recycling efficiency for certain plastics or other materials, might be necessary to drive such changes. The whole funding mechanism and broad organisational arrangements for WEEE and its recycling should also remain under review in this light. Peeters et al. (2013) discuss the implications of two quite different regimes (within the EU and in Japan). They show how the latter scheme, which is much more generously funded at the point of use (i.e. the fees payable for WEEE recycling are much higher per unit) makes more expensive manual dismantling practice economically viable for the recycler. In turn, this considerably improves the recycling rates of many WEEE fractions, with environmental but also economic benefits.

Rough calculations show that these benefits could be used to at least partly offset the increased recycling cost / fee, at least in the specific case of LCD TVs. Peeters et al. (2014) indicate that perhaps €400 per tonne additional material value can be derived from LCD TVs by the more expensive manual disassembly treatment path. The costs are not explicitly outlined, but it seems that a recycling fee of around $€ 20$ per unit is payable under the Japanese scheme. Taking the recycling fee to be a proxy for the true cost (the scheme is non-profit), and the average mass of a LCD TV to be $20-25 \mathrm{~kg}$, means that the total recycling cost is of the order of EUR 800-EUR 1,000 per tonne, and hence about half of this cost can be recovered directly through enhanced material value. There are also consequential avoided costs for incineration and/or landfill if the need for these disposal routes are reduced.

In principle, the economic argument for more onerous and expensive manual disassembly in the interests of enhanced material (including plastics) recycling looks to be a winnable one. Of course, the difficulty and hence cost of disassembly is a function of product design and the current cost levels are reflective of current product design practices. The principles of design for disassembly are an important tenet of Ecodesign. 
Whilst such cleaner production principles and the accompanying Directives do not apply directly to actors engaged in WEEE (plastics) recycling, they are obviously of importance for manufacturers.

A major issue is that ease of disassembly runs counter to general product design trends - of increasing product complexity and heterogeneity, increasing product sleekness, and the use of proprietary or bespoke joints (Sundin et al. 2012). As reported by Ardente et al. (2014), criteria relating to easy disassembly are embedded in certain ecolabelling schemes, including the Nordic Ecolabel, for some product groups. Discussions on embedding ease of dismantling in enforceable policies and standards, possibly encompassing quantitative targets such as time for disassembly, are ongoing. Design for disassembly, in the current climate, may mean "design for automatic disassembly" (Sundin et al. 2012). Overall, there is little to indicate that design for disassembly is considered in any real sense in the design of EEE at present. Gradual reversal of this trend would eventually serve to further narrow the gap between additional recycling costs and obtainable revenues.

One should also remember that the cost recovery levels assume a market demand for recycled plastics. As outlined in Part 1, this is far from guaranteed - work on developing different actor's perceptions of recycled plastics is an essential complement to any changes made in the treatment value chain.

\subsection{Conclusions}

Here we outline the main conclusions arising from the study, organised broadly around the issues listed in the Introduction.

\subsubsection{Range of available technologies, fitness for purpose}

Essentially off-the-shelf technological solutions are available for most issues relating to the separation and recycling of WEEE plastics, especially if one accepts the essential non-recyclability of plastics with flame retardants. The appropriate combination of density, optical and electrostatic methods can yield relatively pure plastic streams. Subject to market perception of and demand for the products there is an economically and technically sound case for the recycling of most WEEE plastics.

The current technological mix is not really fit for purpose in terms of recovering (or effectively separating) plastics containing brominated flame retardants. Regulatory drivers mean that such materials are effec- 
tively non-recoverable, and it seems that fairly substantial quantities of otherwise "clean" plastics are lost in eliminating such material from the value chain. However, specific data on these issues does not appear to be readily available, and further investigation as to the precise scale of the problem is warranted.

\subsubsection{Flexibility and cost of technologies}

High capital costs and the need for investment was identified in Part 1 as a barrier to new players entering the market, and it still seems to be the case that the (Nordic) WEEE plastics recycling market is largely concentrated across rather few, rather large players.

The conventional approach to plastics recycling - similar to the sizereduction scenario outlined above - involves high levels of capital expenditure but thereafter low running costs. Plastics recycling rates are modest and whilst it is necessary to secure markets for the recovered materials, this seems relatively achievable in markets as they currently stand. The manual disassembly approach involves much lower capital expenditure but higher operational and running costs. The overall cost levels are higher but these are offset by the enhanced material recycling (if the additional recovered material can be sold in the market). In some sense, the lower capital costs imply a lowered barrier to market entry, although there is still considerable risk and the need to secure large throughputs over the long-term to develop a sustainable business is arguably just as important as in the automated scenario.

The economic argument for more manually-intensive approaches was described above as "winnable" - but this does not mean that such arguments can actually be won. Indeed, there is evidence to suggest that European recycling facilities based on a fairly manual-intensive working model are coming under pressure (for example BBC News, 2014). As the market currently stands there seems little prospect of new manualintensive facilities coming on-stream.

However, the full economic potential of techniques that enhance material recycling is not realised at present. If WEEE plastics containing flame retardants really can be separated more accurately and selectively than is currently possible, then this would carry an economic premium that is not currently present.

The Japanese example described above shows that a market where headline recycling fees per unit are much higher than current European levels is feasible, at least in principle. As the imperatives for ever improved environmental performance become more prominent, such a 
market becomes increasingly possible. In addition, it seems that more manually-intensive approaches could possibly prove more flexible and adaptable than those with greater automation - although both should be able to deal with varying input flows and "qualities" relatively well.

\subsubsection{Ongoing developments, synergy with other waste plastic streams}

The other major waste plastic streams (notably plastic packaging waste) present generally simpler technical challenges than WEEE plastics. For the most part, the separations are more straightforward and there are few complicating factors such as hazardous materials. Some elements of packaging (e.g. food contact packaging) have stringent quality requirements, but for the most part there are few factors that compromise the combined treatment of plastic wastes from different streams (i.e. packaging waste and WEEE plastics), particularly if hazardous elements of WEEE plastics can be handled satisfactorily. As such, the most promising synergy between WEEE plastics and plastic packaging is that they provide a substantial combined throughput for plastics processing facilities.

In terms of technological developments, little can be expected from density separation or electrostatic techniques. Possibly the most significant ongoing developments concerning optical techniques (NIR) do not concern the technologies themselves, but rather the development of black plastic (additives) that can be detected by NIR, thus potentially solving one of the biggest problems with that particular technique. A large-scale trial in food packaging is currently underway (WRAP 2014). Additionally, work on identifying polymers via auto-fluorescent properties (Langhals et al, 2014) shows some promise in detecting black plastic if it were used in conjunction with NIR.

\subsection{References}

Ardente, F., Mathieux, F., Recchioni, M. (2014). Recycling of electronic displays: Analysis of pre-processing and potential ecodesign improvements, Resources, Conservation and Recycling, 92, 158-171 (http://www.sciencedirect.com/science/ article/pii/S0921344914001955). http://dx.doi.org/10.1016/j.resconrec.2014.09.005

BBC News (2014). Sims recycling plans to cut 99 Newport jobs, http://www.bbc.com/ news/uk-wales-south-east-wales-28547385 (accessed November 2014).

Langhals, H., Zgela, D., Schluker, T. (2014). High Performance Recycling of Polymers by Means of Their Fluorescence Lifetimes, Green and Sustainable Chemistry, 4, 144150 (http://dx.doi.org/10.4236/gsc.2014.43019). 
Peeters, J.R., Vanegas, P., Duflou, J.R., Mizuno, T., Fukushige, S., Umeda, Y. (2013). Effects of boundary conditions on the end-of-life treatment of LCD TVs, CIRP Annals - Manufacturing Technology, 62(1), 35-38 (http://www.sciencedirect.com/ science/article/pii/S0007850613000930). http://dx.doi.org/10.4236/gsc.2014.43019

Peeters, J.R., Vanegas, P., Tange, L., Van Houwelingen, J., Duflou, J.R. (2014). Closed loop recycling of plastics containing Flame Retardants, Resources, Conservation and Recycling 84, 35-43 (http://www.sciencedirect.com/science/ article/pii/S0921344913002723)

Sundin, E., Elo, K., Lee, H.M. (2012). Design for automatic end-of-life processes, Assembly Automation, (32), 4, 389-398 (http://dx.doi.org/10.1108/ 01445151211262447)

WRAP (2014). Recyclability of black plastic packaging, http://www.wrap.org.uk/ content/recyclability-black-plastic-packaging-0 (accessed November 2014). 



\section{Environmental Declarations for Small Consumer Electronics: The Effect of Plastics Recycling}

\subsection{Introduction}

The aim of this study is to investigate how producers of small consumer electronic equipment might be incentivised to improve practice with respect to WEEE plastics recycling, by investigating and highlighting the potential improvements in environmental performance of products resulting from such recycling. Specifically the study addresses how such improvements would manifest themselves in the environmental declarations of various types that are typical of consumer electronic products. Hence, the principal question this study addresses is: "(How) could recycling of WEEE plastics improve the environmental performance of consumer electronics as expressed through typical environmental declarations?"

Clearly, overall improvements in the collection and recycling of WEEE plastics is a responsibility shared along the entire value chain with end consumers, actors in the collection, transport and recycling of waste, policy-makers and governments and other stakeholders all playing important roles alongside electronics producers. Here, we focus on the producers - other parts of the project look at different parts of the value chain in more detail.

This study consists of a brief review of environmental declarations in general and how they are typically used in the consumer electronics sector. There are different types of declarations with different aims and objectives - these are briefly explored and discussed. The study principally focuses on the more involved forms of declarations, generally known as EPDs (environmental product declarations) - which themselves take a number of different forms.

The potential improvement in declarations is explored through some LCA (life-cycle assessment) calculations for developing EPDs for sample products, coupled with a sensitivity analysis involving, for ex- 
ample, the substitution of virgin plastics with recycled ones and/or changes to the recycling / reuse potential of products following such changes. These calculations are based on standard modules in LCA databases for the manufacturing, transport and disposal phases of consumer electronic equipment.

\subsection{Environmental Declarations}

Environmental labelling is benchmarked against the 14020 series of ISO standards (ISO, 2010). Three types of environmental declaration are established:

- Type I declarations (ISO 14024) are essentially eco-labels. There are literally hundreds of eco-labelling schemes worldwide, although some are more prominent than others. These schemes award a label or mark depending on a product meeting a range of environmental criteria, and perform third party verification of claims submitted under the scheme. The list of criteria can be fairly exhaustive (see Nordic Ecolabelling, 2014 for a relevant example) - however the ultimate criterion is purely qualitative, specifically pass/fail products either gain the label or not. The essential simplicity of this is at least in part directed by the principal audience for eco-labels; they are directed at end consumers with a view to raising awareness and encouraging "green" consumer purchasing. The most prominent ecolabelling scheme in the Nordic countries is the Nordic eco-label, also known as the Nordic Swan.

- Type II declarations are standardised by ISO 14021 and are essentially self-declarations. These take various forms but are not (unlike Type I declarations) verified by a third party. They may combine qualitative and quantitative information. Partly because of their lack of independent verification (although declarations in accord with 14021 will meet a range of quality standards) these are arguably of lesser interest than other types of declarations.

- Type III declarations (ISO 14025) encompass much more specific, and specifically quantitative, environmental information than the other types of declarations. These are primarily business-to-business artefacts, for the exchange of detailed environmental information between professionals (for example, from suppliers to prospective and existing customers). These declarations depend on independently verified life-cycle assessments according to other relevant ISO standards. The standard terminology for type III 
declarations is "Environmental Product Declaration" or EPD. Whilst LCA is a general and over-arching approach to examining environmental impact, particular products or product groups may demand a specific focus in a number of ways. These may include the specific environmental indicators of interest, parts of the life cycle that may be neglected or dealt with summarily in the analysis, the specific form of the written output, and so on. Such criteria are contained within Product Category Rules (PCRs) which outline the specific requirements. EPDs and PCRs are - by the requirements of the ISO standard - administered by a programme operator which may, for example, be an industrial sector organisation or scientific body. There are about two dozen programme operators worldwide, with most across Europe, the USA and the Far East. The two principal operators in the Nordic region are the Norwegian EPD Foundation (EPD Norge) and the International EPD System, based in Sweden.

\subsection{Existing EPDs for Consumer Electronics}

This study is focused on the experiences and perspectives of value-chain professionals and hence on Type III declarations - EPDs. Certain industrial sectors, most notably the buildings and related sectors, have embraced the EPD approach much more fully than others, and many EPDs relating to these sectors can be found.

For consumer electronics, a fairly substantial number of EPDs have been prepared but very few can be found in the Nordic databases - one must look to the repositories of the American and Far Eastern operators (for example, UL 2014 and EcoLeaf 2014 respectively) to find examples. The picture is complicated by independent production of environmental declarations by a number of very prominent actors in the consumer electronics market. For example Apple (2014) produces Environmental Product Reports that ostensibly contain some of the quantitative environmental information that would be found in EPDs, but in summary form and with only vague reference to relevant standards. It is debatable over whether such reports are designed for B2B purposes or aimed at end consumers. Hitachi (2009) provides another example of a major actor effectively producing Type II declarations that look superficially somewhat like Type III ones but are actually based on in-house methods and procedures, apparently without reference to global standards and without external verification. 


\subsection{EPD calculations for electronic products}

This study seeks to address the potential effect of recycling WEEE plastics on the life-cycle environmental performance (and hence declaration) of consumer electronic products. To this end, we will perform LCA calculations as if we were preparing an EPD for a product. Many LCA calculations for the manufacture of consumer electronics can be found in the literature (for example, Andrae and Andersen, 2010) but rarely, if ever, is the life cycle inventory data presented in sufficient detail to allow these to be reproduced directly. However, the standard LCA database Ecoinvent, as implemented in the SimaPro LCA software, contains a large number of sample inventory data sets. These include data for the manufacture of representative example electronic devices of many sorts, mostly in the IT / telecommunications area. Since we seek a general picture of the sensitivity of calculations to certain changes (such as materials substitution), these data are perfectly useful for this study.

The calculations for the life cycle impact are performed for the device manufacture as a whole and then repeated for an equivalent "device" consisting of only the plastic components. In certain situations the nature of the models in Ecoinvent means the isolation of plastic components is not straightforward. This requires certain assumptions regarding the composition, but these should have only a minor effect on the overall results. Note also that here we focus on raw materials. Elements of the life cycle relating to materials processing (for plastics, this might include injection moulding) are removed from the plastics "device". This implies that they remain unchanged in the face of any later materials substitution - it is assumed that any plastics processing would be identical for virgin and recycled plastics feedstock.

Device manufacture is an important part, but not the only part, of the life cycle. Some LCA calculations are performed on a cradle-to-gate basis, which implies that the life cycle of interest ends with the manufacture of the device and the downstream parts are not considered. Crucially, however, EPDs are normally presented on a cradle-to-grave basis, which includes the downstream phases of transport to the customer, use, and final disposal / recycling. The use phase of the product is often highly significant - this will be dealt with separately. The waste handling parts of the life cycle are not entirely straightforward, but are also dealt with via standard Ecoinvent modules for end-of-life disposal of the equipment. In the first part of the analysis presented here, we are focusing on the manufacturing parts of the life cycle (effectively cradle-to-gate). Later, we will consider the full life cycle as would be typical for an EPD. 
Focusing on the manufacturing elements is justifiable as these are those that are to some degree in the direct, obvious control of the manufacturer. Nonetheless, principles such as Ecodesign or design for recycling imply that the later life cycle stages are very much the responsibility of the manufacturer also.

In Part 1 of the project, we established a focus on smaller domestic appliances - those in Categories 2-4 of the EU WEEE directive. This encompasses items such as vacuum cleaners, irons, toasters, coffee machines; IT and telecommunications equipment including computers; and other consumer devices including audio and musical equipment. Here we look at some products represented in Ecoinvent that fall into these categories, ideally if there are also published EPDs for such products. The availability of Ecoinvent data leads us to focus on Category 3 devices (IT and telecoms), although we will try and draw general conclusions for different types of device.

EPD calculations for consumer electronics are necessarily somewhat narrow in focus, both in terms of data availability (for example on the composition of electronic devices) and in their range and scope of outputs. For WEEE plastics and recycling, these simplifications are probably most significant with respect to hazardous materials, particularly brominated flame retardants. BFRs are typically not characterised in inventory data for electronic devices. Whilst it is known that BFRs are present in WEEE plastics, the precise quantitative levels thereof are subject to considerable uncertainty (see, for example, Wäger et al. 2010). Life cycle inventory data for the major brominated flame retardants in waste electronics does not appear to be available, and would be based on little more than guesswork if it were.

Perhaps most importantly of all, EPD calculations in practice do not encompass the environmental impact categories, specifically toxicity, for which hazardous materials have a significant effect. Few EPD-like reports make any reference at all to this area - an example of one which does (Apple, 2014) is vague and unspecific, merely stating that products compliant with the European RoHS directive for restricting hazardous substances in electronic equipment. According to the relevant ISO standards, the scope of EPDs in a particular sector are established via Product Category Rules (PCRs) which in turn arise from a sector-wide consensus. Unless and until there is such a consensus to include toxic effects, which seems unlikely in the near future, they will not appear in declarations. 


\subsubsection{LCA calculations: Laptop Computer Manufacture}

In order to assess the potential effects of materials substitution on the environmental performance of products, we first need to examine the breakdown of environmental impact across the manufacturing parts of the life cycle. The Figure below shows such a breakdown for a laptop computer, using the Ecoinvent process: Laptop Computer, at plant, GLO/U.

The data shows that the total mass of the product is $3.15 \mathrm{~kg}$. The obviously identifiable plastics in the inventory are $51 \mathrm{~g}$ of LDPE, $89 \mathrm{~g}$ of polystyrene foam slab and $423 \mathrm{~g}$ of high impact polystyrene. In addition, $99 \mathrm{~g}$ of other plastics are identifiable from the inventory for the printed wiring boards. In total this makes about 662 grams of plastic. This is undoubtedly an underestimate since numerous other components (including batteries, plugs and the hard disk unit) will also contain some plastics. However, the complexity of the product makes isolating all the plastics an unduly onerous task. Data in the literature suggests the approximate plastic composition of a typical laptop as a whole is about $30 \%$, this would imply about 900 grams of plastic here. Hence, the level of plastic is probably being underestimated by perhaps a quarter, but this leads to safe, conservative results in terms of the overall effect of plastics.

The impact assessment concerns characterisation results in LCA for midpoint environmental indicators, since these are the data typically reported in EPDs. The data on global warming potential are invariably of most interest, and these help in comparing results with those in the literature. The results for the main indicators typical of EPDs are as follows:

\begin{tabular}{|c|c|c|c|}
\hline Category & Entire Device & Plastics & Contribution of Plastics \\
\hline Global Warming (kg CO2 equiv) & 199 & 2.6 & $1.3 \%$ \\
\hline Ozone layer depletion (kg CFC-11 equiv) & $1.37 \mathrm{E}-05$ & $1.32 \mathrm{E}-07$ & $1.0 \%$ \\
\hline Photochemical Oxidation (kg C2 $\mathrm{H} 4$ equiv) & 0.0445 & 0.0011 & $2.6 \%$ \\
\hline Eutrophication (kg PO4 - equiv) & 1.4150 & 0.0014 & $0.1 \%$ \\
\hline Acidification (kg SO2 equiv) & 0.9981 & 0.0089 & $0.9 \%$ \\
\hline
\end{tabular}

It appears that plastics manufacture contributes only marginally to the overall environmental impact of the laptop, and that the probable underestimate of the plastics inventory mentioned above will not affect that conclusion. The GWP of about $200 \mathrm{~kg}$ CO2 equivalent is in accord with published LCA calculations in the literature (for example, Andrae and Andersen, 2010). It emerges that about half of the GWP arises from the manufacture of printed wiring boards, about $30 \%$ from metals (specifically magnesium), about $10 \%$ from the LCD module and about $10 \%$ 
from everything else - there are dozens of processes in the full calculation that make small contributions.

It follows that substitution of the plastics with recycled materials, even if this were technically and economically feasible, will have a somewhat marginal effect on the environmental impact associated with device manufacture, and hence the EPD of such a product. The other phases of the life cycle will be considered below.

\subsubsection{LCA calculations: Laser Printer Manufacture}

The above procedure is repeated for the Ecoinvent process: Printer, laser $j e t, b / w$, at plant/GLOU, noting that the impacts seemed broadly similar for colour printers. Relative to laptop computers there is a clear distinction in terms of the plastics content. The weight of the printer without toner is about $4.6 \mathrm{~kg}$, but about $3.2 \mathrm{~kg}$ of this (roughly $70 \%$ ) is plastics of one form or another, mostly HIPS. The relative simplicity of the device compared to a laptop computer - particularly in terms of how it is represented in Ecoinvent - allows the plastics to be isolated easily, and hence comparisons may be found readily for a range of environmental impact categories. The results for the major categories are summarised as follows:

\begin{tabular}{lrrr}
$\begin{array}{l}\text { Table 2: LCA Calculations for laser printer } \\
\text { Category }\end{array}$ & Entire Device & Plastics & Contribution of Plastics \\
\hline Global Warming (kg CO2 equiv) & 52.8 & 11.6 & $22 \%$ \\
Ozone layer depletion (kg CFC-11 equiv) & $3.77 \mathrm{E}-6$ & $4.06 \mathrm{E}-8$ & $1 \%$ \\
Photochemical Oxidation (kg C2H4 equiv) & 0.0126 & 0.0039 & $31 \%$ \\
Eutrophication (kg PO4 - equiv) & 0.1066 & 0.0036 & $3 \%$ \\
Acidification (kg SO2 equiv) & 0.2111 & 0.0401 & $19 \%$ \\
\hline
\end{tabular}

We see that, at least for certain impact categories including GWP, that the plastics have a major contribution to the life cycle impact for the device manufacture. Hence, at least in principle, there is the potential for substantial improvements in overall environmental performance through the use of recycled plastics. 


\subsubsection{LCA calculations: Manufacture of other devices}

For a desktop computer without screen (Ecoinvent: Desktop computer, without screen, at plant/GLO $U$ ) the results are as follows:

\begin{tabular}{lrrr}
$\begin{array}{l}\text { Table 3: LCA Calculations for desktop computer } \\
\text { Category }\end{array}$ & Entire Device & Plastics & $\begin{array}{c}\text { Contribution of Plastics } \\
\text { Global Warming (kg CO2 equiv) }\end{array}$ \\
Ozone layer depletion (kg CFC-11 equiv) & 250.4 & 1.99 & $0.8 \%$ \\
Photochemical Oxidation (kg C2H4 equiv) & $2.501 \mathrm{E}-05$ & $2.849 \mathrm{E}-07$ & $1.1 \%$ \\
Eutrophication (kg PO4 - equiv) & 0.1162 & 0.0016 & $1.4 \%$ \\
Acidification (kg SO2 equiv) & 2.4363 & 0.0022 & $0.1 \%$ \\
\hline
\end{tabular}

Much as for the laptop computer, the plastics manufacture seems to make a marginal contribution to the overall environmental impact of product manufacture.

Finally, by way of contrast with the other findings, the results for a computer keyboard (Keyboard, standard version, at plant/GLOU) are as follows:

Table 4: LCA Calculations for computer keyboard

\begin{tabular}{lrrr} 
Category & Entire Device & Plastics & Contribution of Plastics \\
\hline Global Warming (kg CO2 equiv) & 21.6 & 18.1 & $83.9 \%$ \\
Ozone layer depletion (kg CFC-11 equiv) & $2.271 \mathrm{E}-06$ & $1.539 \mathrm{E}-06$ & $67.7 \%$ \\
Photochemical Oxidation (kg C2H4 equiv) & 0.0061 & 0.0050 & $81.4 \%$ \\
Eutrophication (kg PO4 - equiv) & 0.1969 & 0.1827 & $92.8 \%$ \\
Acidification (kg SO2 equiv) & 0.1468 & 0.1199 & $81.7 \%$ \\
\hline
\end{tabular}

Clearly, the plastics content of the keyboard is higher than for some of the other devices considered. The Ecoinvent module keyboard weighs 1,180 grams and of this at least 870 grams (73\% by weight) is in the form of plastics. Note that this is a similar proportion to the laser printer - but the remaining $30 \%$ or so by weight for the laser printer consists of complex electronic components which yield high impacts for manufacture, whereas for the keyboard most of the rest of the mass is provided by (simple) steel.

\subsubsection{LCA calculations: Use phase}

Calculation of the use phase environmental impact depends on a number of assumptions. For desktop and laptop computers we take the following as outlined in Ecoinvent. We assume office use, with a mix of modes: active for 5.5 hours per day, on standby for 2 hours per day and off for 16.5 hours per day. In these modes the average power draw and hence total power usage per day is as follows: 


\begin{tabular}{|c|c|c|c|}
\hline Use Mode & Daily time & Power Draw & Daily kWh \\
\hline Desktop, active use & $5.5 \mathrm{hrs} / \mathrm{day}$ & $150 \mathrm{~W}$ & 0.825 \\
\hline Desktop, standby use & $2.0 \mathrm{hrs} / \mathrm{day}$ & $45 \mathrm{~W}$ & 0.090 \\
\hline Desktop, off / sleep use & $16.5 \mathrm{hrs} /$ day & $5 \mathrm{~W}$ & 0.082 \\
\hline Total & & & 0.997 \\
\hline
\end{tabular}

\begin{tabular}{|c|c|c|c|}
\hline Use Mode & Daily time & Power Draw & Daily kWh \\
\hline Laptop, active use & $5.5 \mathrm{hrs} /$ day & $190 \mathrm{~W}$ & 1.045 \\
\hline Laptop, standby use & $2.0 \mathrm{hrs} / \mathrm{day}$ & $4 W$ & 0.008 \\
\hline Laptop, off / sleep use & $16.5 \mathrm{hrs} /$ day & $1.5 \mathrm{~W}$ & 0.025 \\
\hline Total & & & 1.078 \\
\hline
\end{tabular}

In addition, as per Ecoinvent we assume 240 days use per year and a product lifetime of 4 years. This gives a life-time use of $957.6 \mathrm{kWh}$ for the desktop and $1034.64 \mathrm{kWh}$ for the laptop. In order to calculate the life-time environmental impact, we then need to assume an electricity mix (the latest Nordic production mix calculated by Ostfold Research). This gives rise to total life cycle impacts in the key categories as follows. First for the laptop:

\begin{tabular}{|c|c|c|}
\hline Category & Manufacture & Use \\
\hline Global Warming (kg CO2 equiv) & 199 & 85.9 \\
\hline Ozone layer depletion (kg CFC-11 equiv) & $1.37 \mathrm{E}-05$ & $3.83 E-05$ \\
\hline Photochemical Oxidation (kg C2H4 equiv) & 0.0445 & 0.0162 \\
\hline Eutrophication (kg PO4 - equiv) & 1.4150 & 0.1111 \\
\hline Acidification (kg SO2 equiv) & 0.9981 & 0.3394 \\
\hline
\end{tabular}

Many other published studies (for example, WRAP, 2010a) show that the use phase contributes as much, if not more, than the manufacturing phase for global warming potential and other indicators. Here, with the exception of ozone depletion, the manufacturing phase is firmly established as the most significant, although the use phase does make a substantial contribution. The differences are probably reflective of different electricity mixes in different parts of the world.

For the desktop computer the results are as follows:

\begin{tabular}{lrr} 
Category & Manufacture & Use \\
Global Warming (kg CO2 equiv) & 250.4 & 79.5 \\
Ozone layer depletion (kg CFC-11 equiv) & $2.501 \mathrm{E}-05$ & $3.550 \mathrm{E}-05$ \\
Photochemical Oxidation (kg C2H4 equiv) & 0.1162 & 0.0150 \\
Eutrophication (kg PO4 - equiv) & 2.4363 & 0.1028 \\
Acidification (kg SO2 equiv) & 1.7269 & 0.3141 \\
\hline
\end{tabular}


Once again, we can say with some confidence that the manufacturing process has the biggest overall contribution. Hence, improvements in manufacture should also give rise to noticeable improvements in the overall environmental performance and hence the EPD. Table 8 shows the equivalent figures for the laser printer.

\begin{tabular}{|c|c|c|}
\hline Category & Manufacture & Use \\
\hline Global Warming (kg $\mathrm{CO} 2$ equiv) & 250.4 & 710.5 \\
\hline Ozone layer depletion (kg CFC-11 equiv) & $2.501 \mathrm{E}-05$ & $5.445 \mathrm{E}-05$ \\
\hline Photochemical Oxidation ( $\mathrm{kg} \mathrm{C} 2 \mathrm{H} 4$ equiv) & 0.1162 & 0.1497 \\
\hline Eutrophication (kg PO4 - equiv) & 2.4363 & 0.4696 \\
\hline Acidification (kg SO2 equiv) & 1.7269 & 3.5243 \\
\hline
\end{tabular}

The use phase dominates, relatively speaking, for most impact categories. However it emerges that the vast majority of the impacts arise from the use of paper - for GWP it is $584 \mathrm{~kg} \mathrm{CO2}$ equivalent. Whilst it is correct in LCA to include this, and an EPD would include such, one could argue that such impacts are not particularly relevant to the (design or recycling of the) laser printer itself, since the lifetime paper throughput is a specified parameter and such impacts are inevitable.

\subsubsection{LCA calculations: Disposal phase}

Calculations for the disposal phase are only summarised briefly here, since it quickly emerges that the disposal processes (including a mixture of landfill, incineration and recycling) make a very limited contribution to the overall life cycle impact. Only results are for Global Warming Potential (kg CO2 equiv) are shown here.

\begin{tabular}{|c|c|c|c|c|}
\hline Device & $\begin{array}{r}\text { Manufacturing } \\
\text { GWP }\end{array}$ & Use GWP & Disposal GWP & $\begin{array}{l}\text { Contribution of } \\
\text { Disposal to total }\end{array}$ \\
\hline Laptop computer & 199 & 85.9 & 2.91 & $1.01 \%$ \\
\hline Desktop computer & 250.4 & 79.5 & 4.52 & $1.35 \%$ \\
\hline Laser Printer & 52.8 & 710.5 & 11.95 & $1.54 \%$ \\
\hline Keyboard & 21.6 & N/A & 1.73 & $7.41 \%$ \\
\hline
\end{tabular}

Note that the use phase of the computer keyboard in Ecoinvent is encompassed in the use phase of the computer with which it is used - and it seems evident that the impact of keyboard use will be almost nil.

The recycling potential (meaning potential environmental credit for the use of recycled materials hence avoiding virgin material production) is not included explicitly here. This is typical for most EPDs involving life 
cycles with open-loop recycling (where the recyclates are eventually made into something other than the source product); according to some PCRs the recycling potential is stated but is given as being beyond the system boundaries. In this study, our focus is in the use of recycled plastics in manufacture rather than (specifically) the eventual recyclability of manufactured products, although both elements are of course desirable. As such, and as outlined above, the potential benefit in WEEE plastics recycling is expressed via the use of recycled plastics as raw materials rather than "recyclable" plastics appearing in products.

\subsection{Discussion}

\subsubsection{Potential effect of plastics recycling on life cycle impact}

This has effectively been dealt with in the above analysis. If virgin plastics are substituted by recycled ones, then depending on a number of factors - such as whether recycling is closed- or open-loop, and how the environmental burdens and benefits are precisely allocated across the new product and the upstream product from which the raw materials are derived - the substituted raw materials come at very low environmental cost. Savings compared to virgin materials can exceed $90 \%$. For the purpose of this study we can arguably neglect altogether the environmental cost of recycled raw materials, hence assume that the potential saving for the device manufacturing stage of the life cycle is the contribution of virgin plastics in the original case.

Given this assumption, and looking at Global Warming Potential (invariably the indicator of most interest), we can see that the potential savings in declared potentials in EPDs vary from 1-2\% for desktop and laptop computers to around $20 \%$ for printers and up to around $80 \%$ for keyboards. These are the simple and direct savings from recycling the plastics in these products. If plastics recycling leads to the enhanced recycling of other constituents of WEEE, for example metals, the savings will be even greater.

It is very clear that typical EPD calculations do not by any means capture the full environmental impact of (waste) electronics. As discussed above, it seems clear that some of the most serious potential impacts arise from hazardous materials and manifest themselves in impact categories relating to toxicity, which are typically outside the scope of EPDs. However this is not of much importance for the key objective of the 
study, which is to examine the effect of good practice in WEEE plastics recycling on environmental declarations as they stand - and how manufacturers might be incentivised as a result. What the scope of EPDs "should" be - and there is a considerable push in various sectors for toxic effects to be included (for example, Perkins and Will, 2014) - is a separate question.

\subsubsection{Effects for other types of devices}

For large white goods, plastics form a significant fraction of the total mass and there is relatively little by way of complex electronics - the bulk of the mass is simple metals. Previous calculations by Ostfold Research (Baxter et. al 2012) demonstrate that the plastics contribution to the global warming potential of device manufacture - and hence the potential saving within an EPD - could be around 20\%.

In contrast, for mobile telephones - even though the plastics content by overall mass is relatively high - the contribution of plastics to the impact of device manufacture, and hence the potential saving through recycling, is relatively low (around 7\% for GWP). This is because even relatively small amounts of complex electronics and precious / rare metals dominate in terms of the overall environmental cost for device manufacture. Recycled plastics here would have relatively little effect.

More generally, it seems evident that the most promising types of electronic equipment in terms of the potential for savings through use of recycled plastics are those with a relatively high plastics content coupled with relatively simple electronics. In the categories of the WEEE Directive most relevant to this study (2-4), certain items in Category 2 would seem to fit these criteria. Vacuum cleaners and related equipment seem to fit the criteria especially well - this is one area where substantial progress has been made in use of recycled plastics (for example, Electrolux 2014).

\subsubsection{Feasibility and market / economic factors}

The technical and economic feasibility of recycling WEEE plastics is assessed elsewhere in this project; it received substantial attention in Part 1 (Norden, 2014) and is also addressed in other Themes within Part 2. The focus here are the feasibility and market factors connected with using recycled plastics in electronics manufacture, particularly with improved environmental product declarations in mind. 
Anecdotal evidence certainly indicates that electronics manufacturers are moving towards the use of recycled plastics. Dell (2014) has announced a new desktop computer manufactured in part from recycled plastics - moreover this is presented as a closed-loop scheme, the source of the plastics being their own take-back and recycling programmes. Earlier work has established the use of substantial amounts of recycled plastics in vacuum cleaners (Electrolux, 2014), washing machines (WRAP, 2008), audio products (WRAP 2010b) and mobile phones (for example, Motorola 2014). Nonetheless, it seems clear that the use of recycled plastics in consumer electronics remains the exception rather than the rule. These examples seem to prove the technical feasibility; the WRAP projects proved particularly enlightening in highlighting some of the technical shortcomings as well as potential advantages of plastics recycling.

The benefits to manufacturers of reduced environmental impact from their products via plastics recycling - and the declaration of such through EPDs - are obvious in principle but difficult to pin down more specifically. Such benefits are in principle able to be monetised and hence evaluated against the costs of using recycled plastics, bearing in mind that some of the "costs" are straightforward barriers such as the perception - accurate or not - that recycled plastics are simply not fit for purpose. There appears to be little or no systematic study of such benefits and costs in any industry to date, and such a study may not be feasible.

Therefore, for the present work it is perhaps sufficient to present the general results and findings, with the expectation that individual manufacturers would examine these in their own specific context.

\subsection{Conclusions}

Depending on how one draws the system boundaries and allocates environmental burdens and benefits along the value chain, WEEE plastics recycling can influence environmental performance, and hence declarations thereof, in one of two ways. Either recycled plastics - from consumer electronics in a closed-loop fashion or from other sources - are identified as raw materials in device manufacture, or the "recycling potential" of the product in question is enhanced by that product's recyclability. However, "recyclability" in itself seems an unconvincing and non-discriminating metric of environmental performance for consumer electronics. Products derived mostly from metals and plastics could be manufactured from virgin materials with very high impact, ultimately being disposed of irre- 
sponsibly, and manufacturers could still justifiably deem them "recyclable". What matters is whether the products are actually recycled.

Enhanced recycling of WEEE plastics could improve the overall environmental performance of small consumer electronics, as expressed in Environmental Product Declarations, by perhaps 20\%. The saving is evidently dependent on a whole host of factors as outlined above (including the type of device, the extent and feasibility of recycling, the manufacturing, disposal and recycling processes, and so on). The analysis shows how the most significant benefits of recycling arise from electronic devices containing substantial quantities of plastics but also, importantly, lack much by way of complex electronics or rare / precious metals. The latter factors will tend to dilute the potential effect of plastics recycling.

Environmental savings via WEEE plastics recycling, and their presentation in product declarations, should result in a realisable economic / market advantage for electronics manufacturers. Clearly some manufacturers have taken steps to explicitly introduce such practices, whilst other manufacturers have the general tenets embedded in their strategic outlook. Next steps include working directly with manufacturers to examine how the message regarding both plastics recycling and its effect on environmental declarations can be spread more widely.

\subsection{References}

Andre, A.S.G and Andersen, O. (2010). Life cycle assessments of consumer electronics - are they consistent? Int. J. Life Cycle Assessment, 15 (8), 827-836. http://dx.doi.org/10.1007/s11367-010-0206-1

Apple (2014). Product Environmental Reports, https://www.apple.com/environment/ reports/ (accessed November 2014).

Baxter, J., Lyng, K-A., Askham, C. and Hanssen, O.J. (2012). Modell for miljøpåvirkning fra behandling av EE-avfall (kjøleskap, mobiltelefon og LCD-skjerm), Østfoldforskning, OR 31.12, Fredrikstad, Norway.

Dell (2014). Dell Introduces New Packaging Takes Greenhouse Gases Out of the Air and Builds PCs Reusing Plastic from Recycled Electronics, http://www.dell.com/ learn/us/en/uscorp1/secure/2014-05-20-dell-environment-closed-looprecycling-aircarbon-packaging (accessed November 2014).

Ecoleaf (2014). Ecoleaf Environmental Label, http://www.ecoleaf-jemai.jp/eng/ (accessed November 2014).

Electrolux (2014). Ultrasilencer Green, http://group.electrolux.com/en/topic/ ultrasilencer-green/ (accessed November 2014).

Hitachi (2009). Environmental Efficiency of Hitachi Products Based on Factor X, http://www.hitachi.com/environment/library/pdf/factorx_en.pdf (accessed November 2014). 
ISO (2010). Environmental labels and declarations: How ISO standards help, http://www.iso.org/iso/environmental-labelling.pdf (accessed November 2014). Norden (2014). Plastic Value Chains, Case WEEE (Waste Electrical and Electronic Equipment) in the Nordic Region, http://www.norden.org/no/publikasjoner/ publikasjoner/2014-542 (accessed November 2014). http://dx.doi.org/10.6027/TN2014-542

Nordic Ecolabelling (2014). Criteria: Product Groups, http://www.nordicecolabel.org/criteria/product-groups/ (accessed November 2014).

Perkins + Will (2014). Expanding LEED V4 Material Health Transparency, http://perkinswill.com/sites/default/files/LEEDv4-EPD_FINAL.pdf (accessed November 2014).

UL (2014). Environmental Product Declarations, http://site.ul.com/global/eng/ pages/offerings/businesses/environment/services/certification/epd/ (accessed November 2014).

Wäger, P., Schluep, M., Müller, E. (2010). RoHS substances in mixed plastics from Waste Electrical and Electronic Equipment, Final Report, EMPA, http://new.weee-forum.org/system/files/documents/rohs20in20mixed20plastics empa_final_2010200920171.pdf (accessed November 2014).

WRAP (2008). WEEE Plastics: Indesit closed-loop recycling trial, http://www.wrap. org.uk/content/weee-plastics-indesit-closed-loop-recycling-trial (accessed November 2014).

WRAP (2010a). Environmental assessment of consumer electronic products, http://www2.wrap.org.uk/downloads/Environmental_assessment_of_consumer_el ectronic_products.90e77248.10214.pdf (accessed November 2014).

WRAP (2010b). Demonstration of recycled content in electrical products, http://www.wrap.org.uk/sites/files/wrap/Demonstration\%20of\%20recycled\%20 content $\% 20 \mathrm{in} \% 20$ electrical $\% 20$ products $\% 20$ summary\%20report.pdf (accessed November 2014). 



\section{Extended Producer Responsibility Schemes}

\subsection{WEEE collection}

A higher level of WEEE plastics recycling requires efficient collection systems. If generated WEEE is not captured there is nothing to recycle, why collection plays a fundamental role in the end-of-life strategy. As much as the collection is a requirement, it might also be one of the major challenges towards increased recycling of WEEE plastics. As the current collection systems in the Nordic countries are highly based on sourcesorting of WEEE, the systems depend on the consumer's behaviour and willingness to contribute to the system.

\subsubsection{Common Principles}

The collection systems for WEEE in the Nordic region are based on the same principles as a result of Directive 2002/96/EC on Waste Electrical and Electronic Equipment. According to the directive the member countries are obliged to impose extended producer responsibility (EPR) for electronic and electrical equipment.

As there can be hundreds of different producers of EEE in a country, the number of collection points could potentially count to an endless amount. The logistics involved for a producer to organise collection of their products from end-users would in most cases be overly expensive. Producer responsibility organisations (PROs) have therefore emerged to set up common collection and recycling schemes on behalf of the producers, thereby fulfilling their producer responsibility (Kunz et al. 2013).

PROs typically charge per type and amount of EEE each producer puts on the market in order to finance the collection, treatment and recycling of the product at its end-of-life. In practice each producer shares the average costs of collectively recycling mixed categories of types of waste products (Kunz et al. 2013).

PROs are generally most effective for collection of waste that is costly to treat. Increased prices for metals recovered from WEEE have increased the volume of waste diverted from PROs to private commercial 
recycling. For example, the amount of valuable WEEE recycled outside of EPR systems in Germany more than tripled between 2006 and 2013. In Austria, for example, recycling prices decreased by $80 \%$ when competitors entered the market in 2006 and challenged the single PRO operating there (Kunz et al. 2013).

\subsubsection{Collection and Recycling Targets in the EU}

When the WEEE directive was imposed in 2002 the collection and recycling target for WEEE was that $4 \mathrm{~kg}$ of WEEE from households should be collected per person and year within each member country. In 2012, the WEEE Directive underwent a major recast (2012/19/EU), which went into force in August 2012. The European member states are expected to transpose the recast into national law by the year 2014. The changes in the WEEE directive have in most Member states not yet been implemented at the time of writing, and it is also the case for the Nordic countries.

Among the changes imposed is the annual collection target that changed from $4 \mathrm{~kg}$ per capita to $45 \%$ of the weight of electrical and electronic equipment sold on average during the three previous years. The target shall be reached by 2016. The new target is expected to substantially increase the amount of WEEE collected (Oswald, 2013). Another difference is the WEEE categories division. The Directive 2012/19/EU (article 2) refers to the ten categories division from 13th August 2012 to 14th August 2018 (transitional period) and from a new six categories division starting from 15th August 2018.

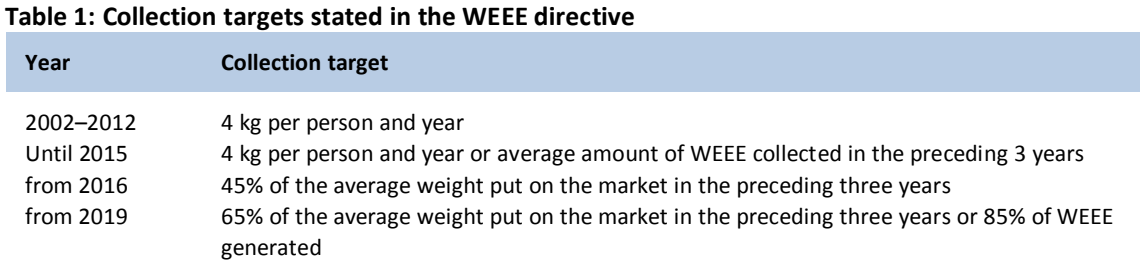

The collection target for Iceland is $6 \mathrm{~kg}$ per capita since 2009 according to a national regulation.

\subsubsection{Different collection approaches}

Common ways of collecting WEEE in the EU, which can also be used in combination, are:

Municipal drop-off: Consumers and or businesses can leave WEEE at municipal drop-off sites. They can either be time-limited arrangements, 
such as a 1-day collection, or a permanent installations. A number of sorting containers/solutions are provided depending on local arrangements with waste contractors.

Kerbside collection: Households might have the possibility to have their WEEE collected close to their property. The collection can be arranged regularly or on request.

Retailer Take Back/point-of-purchase: consumers can return WEEE to retail stores that distribute similar products. This may be dependent upon purchase of a new product, or without any purchase required, and is sometimes done at the point of home delivery and installation of a new item by the retailer/distributor.

WEEE generated from businesses are often collected at a business-tobusiness level, where the generator of the WEEE hires a licensed waste contractor. In some member states it is also possible for businesses to return WEEE to municipal drop-off sites for economic compensation.

The EPR schemes for EEE in place in the Nordic countries are listed in Table 2. The dominating way of collecting WEEE in the Nordic countries is through manned municipal recycling centrals, alongside other waste fractions and recyclables. Retailer take-back is also common as well as collection at a business-to-business level.

\begin{tabular}{|c|c|c|c|c|c|}
\hline & Denmark $^{2}$ & Iceland & Finland $^{3}$ & Norway & Sweden ${ }^{4}$ \\
\hline EPR Schemes & $\begin{array}{l}\text { Elretur } \\
\text { ERP (European } \\
\text { Recycling Platform) } \\
\text { RENE AG (Recycling } \\
\text { Network } \\
\text { Europe) } \\
\text { LWF (Lyskildebran- } \\
\text { chens WEEE } \\
\text { Forening) }\end{array}$ & $\begin{array}{l}\text { RR-skil } \\
\text { Samskil } \\
\text { (The Icelandic } \\
\text { Recycling Fund } \\
\text { will take over } \\
\text { 1-jan-2015) }\end{array}$ & $\begin{array}{l}\text { Serty } \\
\text { NERA } \\
\text { Elker }\end{array}$ & $\begin{array}{l}\text { Renas } \\
\text { Elretur } \\
\text { Elsirk } \\
\text { ERP } \\
\text { Eurovironment }\end{array}$ & $\begin{array}{l}\text { El-Kretsen } \\
\text { EÅF - Elektroni- } \\
\text { kåtervinning i } \\
\text { Sverige Ekono- } \\
\text { misk Förening }\end{array}$ \\
\hline
\end{tabular}

\footnotetext{
2 Danish Ministry of the Environment (2012).

${ }^{3}$ Pannuzzo (2014).

${ }^{4}$ Hemström et al.
} 


\subsection{Defining scheme performance}

Benchmarking collection scheme performance would be valuable in order to determine the efficiency of the systems. Parameters that are often used for the benchmark are collection rate (kg per capita), percentage of recycling for each category and recycling costs. A parameter that is often used in other contexts is collection rate defined as the annual amount collected divided by the annual amount put on the market. This measure is valuable for products with a relatively short lifetime, such as for packaging, where it is reasonable to assume that the amount put on the market an actual year is also collected the same year. For small domestic appliances this assumption cannot that easily be made as the lifetime of the products most likely is several years. With the new collection target, valid from 2016 and expressed in the WEEE directive, the historic amounts of EEE put on the market are taken into account. The historical factors might, however, be perceived as arbitrary not necessarily related to the product life. The collection rate will not be reported on a category basis, but on EEE in general. A common methodology for the calculation of the weight of EEE put on market and a methodology for calculating the amount of WEEE generated by weight in every Member State will be defined by the Commission by 14 August 2015 (Pannuzzo, 2014).

Interesting about the amounts of collected small domestic appliances in the Nordic region is that the collected amounts of small domestic appliances in Denmark, Norway and Sweden are very similar, around $8 \mathrm{~kg}$ per person and year, whereas about half of the amount is collected in Finland (Table 4). An explanation could be differences in amounts put on the market, and according to the Eurostat statistics a smaller amount of SDAs is put on the market in Finland and Iceland (Table 3). Calculating a collection rate (collected amounts/amounts put on the market), paying attention to the fact that the measurement is very uncertain and rough due to product life times and reporting routines, indicate that the collection rates in Sweden, Norway and Denmark are around 80\%, whereas the collection rate of SDAs in Finland is less than $60 \%$, and the collection rate in Iceland under $40 \%$. 
Table 3: Category 2, 3 and 4 put on the market in Denmark, Finland, Norway and Sweden in 2010 (Eurostat, 2014). Data for Iceland is derived from The National Waste Management Plan. Data for later years (2011-2013) is available from the Icelandic Recycling Fund

\begin{tabular}{|c|c|c|c|c|c|c|c|c|}
\hline & \multicolumn{2}{|c|}{$\begin{array}{l}\text { Cat } 2 \text { put on the } \\
\text { market }\end{array}$} & \multicolumn{2}{|c|}{$\begin{array}{c}\text { Cat } 3 \text { put on the } \\
\text { market }\end{array}$} & \multicolumn{2}{|c|}{$\begin{array}{l}\text { Cat } 4 \text { put on the } \\
\text { market }\end{array}$} & \multicolumn{2}{|c|}{$\begin{array}{c}\text { Total put on the } \\
\text { market: Cat 2, } 3 \text { and } 4\end{array}$} \\
\hline & Tonnes & $\begin{array}{l}\text { Kg per } \\
\text { person }\end{array}$ & Tonnes & $\begin{array}{l}\text { Kg per } \\
\text { person }\end{array}$ & Tonnes & $\begin{array}{l}\text { Kg per } \\
\text { person }\end{array}$ & Tonnes & $\begin{array}{l}\text { Kg per } \\
\text { person }\end{array}$ \\
\hline Denmark & 14,074 & 2.5 & 27,165 & 4.8 & 17,760 & 3.2 & 58,999 & 10.5 \\
\hline Iceland & 465 & 1.46 & 1,070 & 3.37 & 731 & 2.30 & 2,266 & 7.1 \\
\hline Finland & 6,202 & 1.1 & 20,603 & 3.8 & 10,414 & 1.9 & 37,219 & 6.9 \\
\hline Norway & 15,572 & 3.1 & 16,055 & 3.2 & 25,246 & 5.0 & 56,873 & 11.3 \\
\hline Sweden & 22,822 & 2.4 & 42,212 & 4.4 & 29,962 & 3.1 & 94,996 & 9.9 \\
\hline
\end{tabular}

Table 4: Collected amounts of category 2, 3, and 4, in Denmark, Finland, Norway and Sweden in 2010 (Eurostat, 2014)

\begin{tabular}{|c|c|c|c|c|c|c|c|c|}
\hline & \multicolumn{2}{|c|}{ Collected Cat 2} & \multicolumn{2}{|c|}{ Collected Cat 3} & \multicolumn{2}{|c|}{ Collected Cat 4} & \multicolumn{2}{|c|}{$\begin{array}{l}\text { Total collected } \\
\text { Cat } 2,3 \text { and } 4\end{array}$} \\
\hline & Tonnes & $\begin{array}{l}\text { Kg per } \\
\text { person }\end{array}$ & Tonnes & $\begin{array}{l}\text { Kg per } \\
\text { person }\end{array}$ & Tonnes & $\begin{array}{l}\text { Kg per } \\
\text { person }\end{array}$ & Tonnes & $\begin{array}{l}\text { Kg per } \\
\text { person }\end{array}$ \\
\hline Denmark & 3,561 & 0.64 & 18,325 & 3.3 & 23,182 & 4.18 & 45,068 & 8.1 \\
\hline Iceland & 68 & 0.21 & 455 & 1.43 & 245 & 0.77 & 768 & 2.4 \\
\hline Finland & 1,320 & 0.25 & 8,034 & 1.5 & 12,117 & 2.26 & 21,471 & 4.0 \\
\hline Norway & 7,592 & 1.55 & 16,496 & 3.37 & 18,479 & 3.78 & 42,567 & 8.7 \\
\hline Sweden & 8,959 & 0.96 & 31,756 & 3.39 & 37,809 & 4.03 & 78,524 & 8.4 \\
\hline
\end{tabular}

Other factors that are believed to influence positively on the collected amounts of WEEE are relatively small populations ( $<15$ million), strong and centralised trade associations and industrial lobbies able to create consensus, development and management of national programmes, a culture of recycling and environmental awareness, and a proven track record in establishing other recycling schemes (tyres, batteries, end of life vehicle etc.) (European Commission, 2006).

\subsection{Areas of improvement to increase collection of WEEE plastics}

The following chapter includes a list of defined areas of improvements with focus on collection in order to increase the recycling of WEEE plastics. In chapter 4 , speculations and suggestions about how these challenges for WEEE plastic recycling can be overcome are discussed. 


\subsubsection{Lack of incentives to hand in WEEE to recycling}

One of the identified improvement areas is more difficult that it may sound - it is about having access to WEEE. Large amounts of WEEE are piled up in the society, and recycling is thus not possible. Accumulated WEEE represents both a potential environmental hazard and an important resource stock. Motivating the public to hand in small WEEE to recycling is therefore a key challenge for increased recycling of WEEE plastics. In a Swedish study the total amount of accumulated WEEE per person was estimated to $160 \mathrm{~kg}$ per person. As the evaluation is based on mass it is no surprise that category 1 - Large household appliances, dominated. Accumulated amounts of small domestic appliances, category 2, 3 and 4, were estimated to 11,15 and 13 kilos per person. Results from these kinds of studies do not, however, tell whether the products are in use or just stocking up. This distinction is of course important, but hard to measure (Hemström et al. 2012). A way of measuring it is by surveys where people are asked how many items of a certain product they have at home. In a Norwegian study it was estimated that around 10 million mobile phones are stored in people's home, in addition to the mobile phones in use. According to the survey, $60 \%$ of the Norwegian population has more than two mobile phones at home that are not in use. Results from Ongondo and Williams (2011) indicate that $60 \%$ or more of mobile phones are retained at end-of-life by users. In Finland It has been estimated that more than $50 \%$ of the Finnish consumers store their non-used mobile phones at home, and only $10 \%$ of them recycle their old mobile phones (Pannuzzo, 2014).

\subsubsection{Awareness raising}

Higher collection results require awareness and attention from the public. How and where small domestic appliances can be disposed of needs to be communicated and perceived (Sinha et al. 2007). As the current collection systems in the Nordics are based on source-sorting there is need for consumers to contribute to the system if WEEE should be handed in. There is a challenge in creating awareness towards the return of discarded appliances to the designated drop-off points. It also requires that a certain budget is spent on communication. 


\subsubsection{WEEE in residual waste and other waste fractions}

On the EU-level it is estimated that only one third of generated WEEE is reported as separately collected and treated. Other paths of WEEE are for example the ordinary waste bin, especially for small domestic appliances (Sinha et al., 2007). Such numbers are not representative for the Nordic countries, but there is still a non-negligible amount of SDAs ending up in fractions not dedicated for WEEE. This causes WEEE two major problems. It represents a loss of recyclable material and can lead to pollution of other waste streams. An estimation of the amount of WEEE found in residual waste in household's bins and bags every year in the Nordics (excluding Greenland, the Faroe Islands and Åland) is around 30,000 tonnes of WEEE, and 7,000 tonnes of WEEE plastics. ${ }^{5}$ This estimate is based on results from waste analyses of residual waste in bins and bags. It should be noted that the variation in results is significant, and that up-scaling of results from waste analyses always should be made with precaution. It is however, possible to conclude that the amount of WEEE discarded in the residual waste is not negligible.

\begin{tabular}{|c|c|c|c|c|}
\hline & \multicolumn{2}{|c|}{$\begin{array}{l}\text { Estimated amount of WEEE in bins and bags } \\
\text { from households }\end{array}$} & \multicolumn{2}{|c|}{$\begin{array}{l}\text { Estimated amount of WEEE plastics in } \\
\text { bins and bags from households (tonnes) }\end{array}$} \\
\hline & Tonnes per year & Kg per person and year & Tonnes per year & Kg per person and year \\
\hline Denmark $^{6}$ & 2,900 & $<1$ & 600 & $<1$ \\
\hline Finland $^{7}$ & 9,600 & 1.8 & 2,140 & 0.4 \\
\hline Iceland $^{8}$ & 580 & 1.8 & 130 & 0.4 \\
\hline Norway $^{9}$ & 8,600 & 1.7 & 1,500 & 0.3 \\
\hline Sweden ${ }^{10}$ & 12,400 & 1.3 & 2,800 & 0.3 \\
\hline
\end{tabular}

Dahlén et al (2013) analysed the purity of source-sorted plastic packaging waste from households in five different Swedish municipalities. In average, 1.3 weight $\%$ of the fraction plastic packaging waste fraction contained hazardous waste, to a majority WEEE. Figures on the amount of WEEE in fractions dedicated to plastic packaging waste have not been

\footnotetext{
${ }^{5}$ Assuming an average content of plastics in SDAs of 20\% (Mepex, 2013).

6 Based on Miljøstyrelsen (2012).

${ }^{7}$ Based on a total generation of household residual waste of 1.2 million tonnes per year (HSY, 2013), and that 0.8 weight \% is WEEE (Pannuzzo. 2014)

${ }^{8}$ Estimation based on the average amount of hazardous waste of $2.4 \mathrm{~kg}$ per capita (Sorpa. 2013). WEEE is thus assumed to be the main constituent, and assumed to 1.8 per capita and year.

${ }_{9}^{9}$ Based on results from waste analyses (Mepex, 2012).

10 Based on Hemström et al. (2012).
} 
able to obtain for other Nordic countries. Applying this percentage on the average amount of the fraction plastic packaging waste per person gives an indication that the total amount of WEEE among plastic packaging waste in Sweden could be somewhere around 500-1,000 tonnes per year. Data from other Nordic countries could not be obtained, but the Swedish data shows that the content of WEEE in other waste fractions than residual waste is important to take into consideration. Plastic packaging waste could be specifically looked at as a lot of WEEE contains a significant amount of plastic.

\subsection{Possible improvements for collection and recycling of higher amounts of WEEE plastics}

\subsubsection{Physical planning}

An existing and convenient infrastructure for WEEE waste management is crucial in order to increase WEEE plastics recycling. For example, farreached drop-off points might hamper people's willingness to source-sort (Finnveden et al. 2007). A method for benchmarking different types of WEEE collection systems would help to further distinguish inefficiencies.

\subsubsection{Increased use of kerbside collection systems}

Kerbside collection systems tend to favour collected amounts of waste according to studies from Sweden and Norway (e.g. Dahlén et al. 2013). The scope of these studies were limited to packaging waste, but showed that the possibility to source-sort packaging waste at the kerb favours the amounts and purity of the collected packaging waste. Experience and knowledge gained from studies performed on other waste flows may as well be used and applicable for WEEE. Introduction of kerbside collection of WEEE in a residential area in focus for a case study in Sweden proved to reduce the amounts of WEEE in the residual and dry recyclables fraction. The amount of non-source-sorted smaller WEEE did not, however, decrease as much as for larger WEEE, which implies that kerbside collection systems for source-sorted larger WEEE might not be ideal for smaller WEEE (Bernstad et al. 2009). 


\subsubsection{Increase the availability to hand in small domestic appliances for recycling}

Decreasing the effort to hand in small domestic appliances for recycling should favour a higher level of recycling of WEEE plastics. Small domestic appliances are normally accepted where other WEEE fractions are taken care of, such as at manned municipal recycling centrals. However, such an activity might require planning as the locations of municipal recycling centrals are often not close to where people do their daily business. When the effort to hand in small domestic appliances is considered too time-consuming or too much of a project there is a risk to find SDAs where it does not belong, such as in residual waste.

There are, however, local initiatives where small domestic appliances are collected. Such an initiative is "Samlaren" in Sweden. Samlaren is a security locker for small hazardous waste, there among small domestic appliances. Samlaren is generally placed in supermarkets, close to where people do their daily business. There are now over 280 samlaren placed out throughout Sweden (Renova, 2014).

Postal services for SDAs are also a possible option. Prepaid envelopes downloadable from the internet can be used for applications such as mobile phones, and left in the nearest mailbox (Pannuzzo, 2014). WEEE, and small domestic appliances, is a heterogeneous fraction why collection systems targeted on SDAs in general, as well as certain fractions of SDAs, e.g. mobile phones, is possible to increase the availability. 


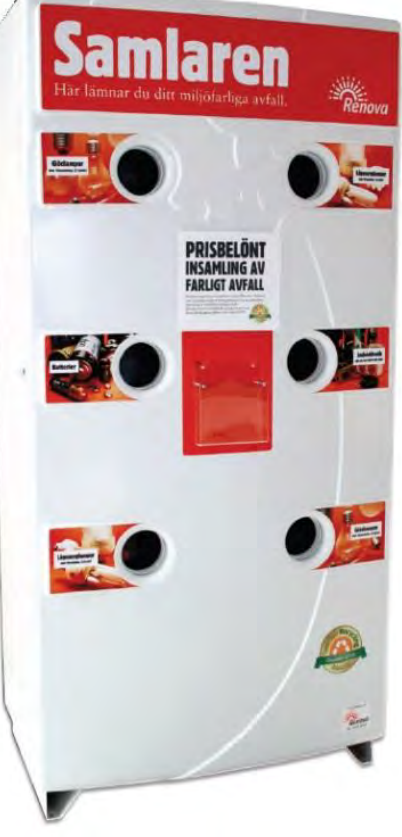

Source: Renova.

\subsubsection{Deposit refunds}

The introduction of deposit refunds for small WEEE items is an alternative to more traditional collection systems, which potentially is useful for waste causing problems if poorly managed. It can be due to risk of spreading hazardous substances if improperly managed, to get hold of materials of high value and to avoid risk of littering (European Commission DG Env, 2012).The economic incentive to return WEEE for recycling is strengthened with deposit refunds.

Deposit return systems for certain small WEEE items are on the agenda in the Nordic countries and in the EU. Deposit return systems for mobile phones have been investigated in Norway. The aim of the project was to evaluate the need for such a system and in that case find out how the system can be implemented in cooperation with the existing collection systems for WEEE. One of the main conclusions from the report is that a deposit return systems will have a positive effect on collected amounts, but a problem that needs to be solved is that personal information will not be erased. A high deposit might result in risk for robbery of old mobile phones why the deposit should be kept at as a low level as possible (Baastad, 2014). 


\subsubsection{Deepened knowledge about current status of WEEE plastic recycling/monitor performance of WEEE plastic recycling}

Part 1 of this study makes it clear that the current status of WEEE plastic recycling is only well known at the most overall and general level. Data from bodies such as Eurostat give a reasonably clear statistical picture for WEEE as a whole, but as soon as the focus moves to plastics, knowledge is based mostly on assumptions and estimates.

From the findings in Part 1, most of the following elements of information could be determined in greater detail and this would offer potential for enhancement in recycling:

- Overall amount of plastics in WEEE - for WEEE put on the market, manufacturers could in principle supply the data if they were required to. For WEEE collected, producer responsibility organisations (PROs) could possibly determine this data but it would require much more detailed scrutiny than is currently typical.

- Overall data on WEEE plastics treatment routes - in principle this could be calculated from data that PROs should have but do not make available, but almost certainly would require additional datagathering and analysis.

- Data on exports of WEEE plastics - the difficulty in this for WEEE as a whole was discussed in Chapter 2. Particularly given the dubious legality of activity in this area, it is difficult to conceive that much better estimates than at present are achievable.

- Losses from collection / transport / storage - once again these will be difficult to pin down but improved traceability, as discussed in Chapter 3, would help.

- Specific mix of plastics in WEEE, including specific data on hazardous substance levels - in principle this would be achievable if manufacturers were required to make available very specific bills of materials / composition data for EEE; in practice this seems hopelessly unrealistic.

Improvements in this area ultimately depend on legislation and evaluation of performance of e-waste management. This is currently based upon amounts (of WEEE, not plastics) collected and how the collected amounts are treated. The targets are followed up based on the EEE product categories, but not on a material level. This means that the status and levels of WEEE plastics recycling is not available, and not fol- 
lowed up specifically. The producer responsibility schemes are not obliged to report how much of the collected WEEE plastics that is actually recycled. In addition, the recycling targets are based on weight of the WEEE leading to a risk that a low recycling level of WEEE plastic waste provides little change to the overall recycling rates.

Measuring, following-up and communicating more specifically on the fate of WEEE plastic waste will ultimately depend on targeted regulatory (and possibly economic) drivers. These are discussed above in Chapter 4 and revisited in Chapter 7. Specific recycling targets for specific materials including plastics are probably the simplest driver that could be implemented.

\subsubsection{Incentivise better performance of EPR schemes}

The principle of many EPR schemes (not only for EEE) is that the fees introduced to cover the collection and recycling of WEEE only cover the fraction of WEEE that is collected and recycled within the EPR collection scheme. Under those premises, the lower the recycling rate, the lower the cost will be, which has the effect that obligated producers have an incentive to maintain performance at low levels. Requirements to fully fund all collection, sorting and treatment of the target waste, including that parts which remains in the residual waste stream (i.e. that does not pass through the EPR scheme) (European Commission DG Env, 2012).

This problem might be overcome by requiring that the fees paid by the producers also cover the fraction of WEEE that is not recycled, which ends up as a part of the residual waste system. This would provide more incentive for producers to make sure their products are recycled to a higher extent (European Commission DG Env, 2012).

\subsection{References}

Baastad D-F (2014). Utredning av obligatorisk panteordning for småelektronikk.

Bernstad A, La Cour Jansen J, Aspegren H (2009). Evaluation of Property Close Sourceseparation of Hazardous Waste and Waste Electronic and Electric Equipment - a Swedish Case Study.

Dahlén L, Vukicevic S, Tapper M (2013). Återvinning av plast från hushållsavfall. Insamlingsresultat och kvalitet av källsorterad plast 2013. Plastkretsens stiftelse för forskning.

Danish Ministry of the Environment (2012). Greening of Electronics. Environmental Project No. 1416, 2012.

European Commission (2006). Implementation of the Waste Electric and Electronic Equipment Directive in the EU. Directorate-General Joint Research Centre. 
Eurostat (2014). Waste Electrical and Electronic equipment. http://epp.eurostat. ec.europa.eu/portal/page/portal/waste/key_waste_streams/waste_electrical_ electronic_equipment_weee

European Commission DG Env (2012). USE OF ECONOMIC INSTRUMENTS AND WASTE MANAGEMENT PERFORMANCES. Final Report Contract ENV.G.4/FRA/2008/0112. http://www.ieep.eu/assets/1301/Waste_economic_ instruments_-_Final_report_-_10_April_2012.pdf

Finnveden G, Björklund A, Carlsson Reich M, Eriksson O, Sörbom A (2007). Flexible and robust strategies for waste management in Sweden. Waste Management, 27, S1-S7. http://dx.doi.org/10.1016/j.wasman.2007.02.017

Hemström H, Stenmarck A, Sörme L, Carlsson A (2012). Kartläggning av flöden och upplagrade mängder av elektriska och elektroniska produkter i Sverige 2010. SMED Rapport nr 115, 2012.

HSY (2013). Pääkaupunkiseudun kotitalouksien sekajätteen määrä ja laatu vuonna 2012. ISSN (pdf) 1798-6095. (Quality and quantity of household mixed solid waste in the Helsinki metropolitan area 2012. In Finnish.).

Kunz N, Atasu A, Mayers K, Van Wassenhove L (2013). Extended Producer Responsibility: Stakeholder Concerns and Future Developments. A report prepared by the INSEAD Social Innovation Centre with the support of European Recycling Platform (ERP).

Mepex (2013). Increased Utilization of the Resources in Plastics Waste. The Norwegian Climate and Pollution Agency

Miljøstyrelsen (2012). Kortlægning af dagrenovation i enfamilieboliger. Miljøprojekt nr. 1414, Miljøstyrelsen.

Ongondo, F.O. and Williams, I. D. (2011) Mobile phone collection, reuse and recycling in the UK. Waste Management, vol 31, No 6, pp 1307-1315.

http://dx.doi.org/10.1016/j.wasman.2011.01.032

Pannuzzo B (2014). Material Flow Analysis on Domestic High Value WEEE Generation and Collection in Finland. Master's thesis. Aalto University School of Engineering.

Renova (2014). Personal communication with David Dalek. 2014-06-11.

Sinha et al. (2007). WASTE ELECTRICAL AND ELECTRONIC EQUIPMENT EU-INDIA ACTION PLAN SUPPORT FACILITY - ENVIRONMENT. http://www.eeas.europa.eu/ delegations/india/documents/eu_india/final_e_waste_book_en.pdf

Sorpa (2014). Ársskýrsla 2013. (e. Annual Report). http://www.sorpa.is/files/ arsskyrslur/arsskyrsla_sorpa_2013_net.pdf). 



\section{Discussion, Conclusions and Recommendations}

\subsection{Overall findings of the study}

In this section we bring together the key findings from each of the five themes and develop over-arching conclusions and recommendations for the value chain as a whole and individual actors in it. In doing so we assemble the evidence to support the principal finding:

\footnotetext{
Central thesis of the study:

The overall funding level of EPR schemes and hence the financial flows through such schemes are essentially arbitrary / subjectively chosen. For WEEE, tariff levels (those fees paid by producers to fulfil their extended responsibility) supposedly reflect the true net costs of waste processing and treatment. However, the extent and quality of waste treatment, and hence the cost level, is a matter of choice. European EPR schemes for WEEE are low-cost with consequent compromises on the quality of treatment. Costlier, higher-quality alternatives would give rise to many substantial advantages over existing schemes, not least in the environmental perspective. Additional costs would be at least partly offset by additional benefits of higher quality waste treatment. Substantial enhancement of WEEE plastics recycling is probably not possible without some restructuring of the cost base.
}

That EPR scheme funding levels are essentially arbitrary / subjective may seem peculiar. However, the evidence from large-scale studies such as that reported by the European Union (2014) seems indisputable. Across a whole range of product groups (batteries, vehicles, oils, packaging, WEEE) there are consistently radical differences in cost / tariff levels in different countries for ostensibly identical treatment services. Whilst of course, as the study reports, there are numerous factors influencing the cost levels in different countries, it is unquestionable that there are qualitatively different levels of treatment (cost) across different territories also. 


\subsection{Summary of key findings from theme investigations}

\subsubsection{Overall direction of waste theme}

The diversion of waste material outside the official EPR value chain means that value is constantly being extracted from the scheme, in both legal and illegal ways. To some degree this is inevitable with elements of the material having positive value, but this is arguably exaggerated in an ultra low-cost EPR environment. Threats to the scheme arise where actors outside the scheme incentivise waste-holders to divert waste (be it scrap metal dealers offering payment for waste, or companies buying mobile phones through the post). Illegal waste exports form the biggest such threat. An EPR scheme with a somewhat higher overall cost base would allow the possibility of offering waste-holders viable alternatives (maybe including revenue-sharing from recycling, or deposit refunds for consumers), hence working against these threats.

\subsubsection{Traceability theme}

Traceability of wastes through the value chain could be radically improved (at additional cost) using essentially existing infrastructure. This could have substantial positive influences on the quality of WEEE processing and treatment, and ultimately recycling levels of many materials including plastics. In part the change would imply more assiduous implementation of existing policies and protocols - for example in recordkeeping, measurement or analysis. Otherwise, this could include new technologies and innovation such as smart labelling. This will allow both existing regulatory drivers to be satisfied but also facilitate increasing quality in the treatment value chain.

\subsubsection{Technology theme}

Higher cost recycling approaches, based around increased levels of manual sorting compared to conventional current practice for WEEE, are shown to deliver tangible benefits in terms of materials recycling and separation. In turn this delivers considerable environmental benefits. The current technology mix is not completely fit for purpose, but the way forward (in the short-term at least) seems to be to reduce the level of technological sophistication, not to increase it. Perhaps somewhat ironically, operating in a lower-tech yet higher cost / revenue environ- 
ment might also facilitate the research and innovation needed to bring the technological solutions up towards the current performance levels of low-tech solutions. Hazardous materials could potentially be handled in a much more environmentally benign fashion than is currently the case. Fair assessment and funding of treatment schemes should recognise this, with an economic premium being placed on features such as highquality handling of hazardous substances.

\subsubsection{Environmental declarations theme}

Environmental declarations show how enhanced recycling of (WEEE) plastics delivers tangible, declarable environmental benefits. These should be monetizable and hence potentially foster more of a design for recycling culture than currently exists.

In light of the discussions on treatment quality, an interesting example which has not yet been considered might be to assess the differential environmental effect of "high-quality" treatment as opposed to that which is undertaken today. However this would require a broadening of scope beyond EPD calculations (taking into account for example toxic effects) to be effective.

\subsubsection{EPR theme}

The funding of WEEE treatment through EPR schemes currently only reflects what is done and how it is done, i.e. it only reflects the WEEE in the scheme that is collected and recycled, effectively ignoring the material outside the scheme. Instead, the amount of material treated is regulated by overall collection targets. These provide no incentive for recyclers or other actors to meet more than minimum threshold standards. The targets being weight-based means that plastics in WEEE are particularly vulnerable to being overlooked or ignored. In theory the change of collection targets to being expressed as proportions of material put on the market should drive increased collection and recycling, but the regulatory drivers look far too crude and coarse-grained to truly incentivise better practice.

As for other elements highlighted in this report, the current situation is reflective of a low-cost and relatively low-quality recycling system. As suggested in different themes, raising funding levels generally should assist in driving up quality. However there remains the question of how this is done. Differential fees / tariffs based on better recycling of certain materials offers one possibility. This is recognised as reasonable and 
sensible, but difficult to implement in practice (OECD, 2014). A somewhat cruder but possibly workable approach would be to introduce collection and recycling targets for specific materials, rather than the WEEE stream as a whole as at present. This could be particularly useful for plastics which are readily overlooked in favour of other, heavier elements in current systems that are on an overall weight basis.

The theme also addresses a number of ways in which collection and recycling could be improved from the consumer standpoint. This is more to do with WEEE as a whole than plastics therein, but all these steps would help to enhance plastics recycling, if coupled with the other suggested measures to develop recycling and treatment practice.

\subsection{Recommendations}

The sector, led by governments and regulators, should fundamentally reexamine the cost / funding basis for WEEE treatment and recycling in Europe.

In the first instance it should be recognised that cost levels are reflective of treatment quality, and that the level of quality is to some degree a matter of choice / consensus. Plastics recycling is (seen to be) at the "high-quality treatment" end of the WEEE treatment spectrum. At present, it is very much secondary to metals recovery in the practice of recyclers. As such, enhanced funding directed at raising quality should specifically bring plastics recycling more into focus.

Regulators should eventually implement a higher-cost, higher-quality treatment regime for WEEE and plastics. Convincing consumers will be essential.

Assuming that taxpayer subsidy of this activity is an unrealistic prospect, any additional costs for treatment and recycling will ultimately be borne by consumers in the form of increased prices for consumer electronics. Even though collection and treatment costs are a relatively small fraction of sales price, there will be an argument to be won.

Regulatory instruments should reward high-quality waste treatment more than punish low-quality practice.

It may well be the case that the European electronics sector would not voluntarily countenance moves towards a higher-cost, higher-quality treatment regime (although such has been seen elsewhere in the world), in which case additional regulatory drivers may be needed to drive up 
quality. In the first instance these could be as simple as specific collection and recycling targets for particular materials.

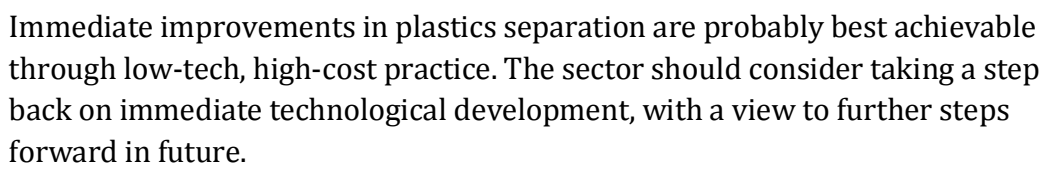

The current technology mix cannot deliver the highest levels of treatment quality with respect to plastics recycling. Immediate moves towards more costly lower-tech solutions to initially deliver the higherquality treatment should be coupled with further technological research and innovation. Ongoing projects to address the non-detectability of black plastic via NIR are good examples of this.

\section{Extended Producer Responsibility schemes should be structured so as to promote Design for Recycling.}

Design for recycling (DFR) is not particularly encouraged by EPR schemes as they currently stand, and there are even some tangible disincentives, such as equal EPR fees for manufacturers meaning that those engaging in DFR effectively subsidising those who do not (OECD, 2014). This study has highlighted how the environmental advantages of design for recycling could be calculated and communicated within the marketplace. This could lead to some realisable benefits for electronics producers. However it seems clear that EPR schemes themselves can do more to promote design for recycling. The general drive towards higherquality treatment, perhaps coupled with regulations designed to reward good practice rather than merely establish minimum threshold standards, should in the long-term promote more of a culture where design for recycling is positively encouraged.

Communication and partnership across and along the value chain is essential.

In the first instance, the above recommendations depend fundamentally on "unilateral" action by governments and regulatory bodies - in that improvements in practice will necessarily be driven by regulations. However this in itself requires considerable consensus between different national authorities, and in turn with the sector as a whole. In practice, ongoing developments in all the above areas are also dependent on co-operation from actors at all parts of the value chain. Fora such as the workshops and events organised by the Nordic Council, both within the plastics recycling projects and otherwise, provide great opportunities 
for building the necessary networks and partnerships. More such events should be organised on a regular basis.

\subsection{References}

European Commission DG Env. (2014). Development of Guidance on Extended Producer Responsibility (EPR), Final Report http://ec.europa.eu/environment/waste/ pdf/target_review/Guidance\%20on\%20EPR\%20-\%20Final\%20Report.pdf OECD (2014). The State of Play on Extended Producer Responsibility (EPR): Opportunities and Challenges, Global Forum on Environment: Promoting Sustainable Materials Management through Extended Producer Responsibility (EPR), http://www.oecd.org/ environment/waste/Global\%20Forum\%20Tokyo\%20Issues\%20Paper\%2030-52014.pdf 


\section{Sammendrag}

Denne rapporten er resultatet fra Del II av prosjektet "Nordic plastic value chains, Case WEEE (Waste Electrical and Electronic Equipment)," initiert av Nordisk Avfallsgruppe (NAG). Som en del av rapporten er det utarbeidet en kortfattet veileder for innsamling og materialgjenvinning av plast fra elektrisk og elektronisk avfall, vist i Annex A.

Rapporten bygger på resultatene fra Del I av prosjektet, som viste at det, til tross for at gjenvinning av EE-avfall generelt ligger på verdenstoppen i Norden, er rom for betydelige forbedringer i systemet. Marked og økonomiske faktorer ble identifisert som de viktigste, fremfor mer tekniske utfordringer.

Økt materialgjenvinning av plast fra EE-avfall krever at det tas ansvar gjennom hele EE-avfallets verdikjede. Forbedringsmuligheter for de ulike aktørene gjennom verdikjeden er derfor vurdert. Studien viser at verdikjeden for gjenvinning av EE-avfall generelt er effektiv, mens materialgjenvinning av plast fra EE-avfall ser ut til å være mindre effektiv. Det vil kreve ekstra kostnader å redusere de tekniske og økonomiske barrierene for $ø$ kt materialgjenvinning av plast, men denne investeringen vil kunne resultere i vesentlige forbedringer. Tiltak som kan medføre økte mengder og økt kvalitet på innsamlet plast fra EE-avfall er viktig for å oppnå økt materialgjenvinning. Dette vil medføre økte kostnader, men disse kan, til en viss grad, bli oppveid av økt materialgjenvinningsgrad. Denne type tiltak kan også redusere mengden EE-avfall som havner på avveier utenfor offisielle kanaler, samt øke mulighetene for å styre avfallsstrømmene som kan inneholde farlige stoffer til riktig behandling. Rapporten er en del av de nordiske statsministrenes initiativ om grønn vekst: "The Nordic Region - leading in green growth." Mer info om dette kan finnes i det internettbaserte magasinet "Green Growth the Nordic Way" på www.nordicway.org eller på www.norden.org/greengrowth 



\section{Annex A: An Illustrated Guide to Good Practice in WEEE Plastics Recycling}

The Guide to Good Practice is attached as a separate document.

In compiling the Guide we have attempted to synthesise the main conclusions and recommendations of the study, and organise them according to the primary stakeholder at which the recommendation is directed. The Guide outlines two principal recommendations for each of the following stakeholder groups:

- Consumers.

- Authorities and Policy-Makers.

- Recyclers and Waste Operators.

- Electronics Producers.

Some parties may be interested in all the recommendations, others perhaps only those for a single group - in particular, consumers may have limited interest in recommendations for other stakeholders. As such, parts of the Guide could be produced as one double-sided page "factsheets" directed at individual stakeholders.

However, (widespread) dissemination in print is not economically feasible. Hence dissemination will proceed electronically and as such, distribution of the Guide as a whole to all interested parties carries little risk.

Dissemination to consumers is probably most feasible by indirect means. Opportunities should be investigated for articles in the popular press which can highlight the existence of the guide and the project, either via the Nordic council website or the websites of the individual project partners.

Dissemination to authorities and policy-makers: an extensive list of specific contacts in the Nordic region and across Europe can be compiled readily from existing contacts. The network of national environmental protection agencies should be a start-point. Indirect dissemination via 
presentations in relevant fora and conferences should also be investigated. NAG will presumably be able to advise extensively on this.

Dissemination to recyclers and waste operators: most of the major players in the Nordic region are already known to us. Further afield across Europe, making use of existing contacts in bodies such as EERA (European Electronics Recyclers Association) should enable more widespread dissemination.

Electronics producers have been the most challenging group to bring on board in the project proper, and this may also prove to be the case with dissemination of the outcomes. The project team have a limited number of specific contacts in individual companies, however further contacts have to be identified. 
Nordic Council of Ministers

Ved Stranden 18

DK-1061 Copenhagen K

www.norden.org

\section{Plastic value chains: Case: WEEE \\ (Waste Electrical and Electronic Equipment)}

This project identifies improvements in plastics recycling from Nordic electronic waste. Limited improvement is possible through modest changes in the existing value chain, such as ensuring that wastes are directed as intended. But for the most part, enhanced plastics recycling implies higher costs. The necessary changes could be driven in part through revised policy and regulatory instruments. These changes might, in turn, encourage more positive engagement from electronics producers.

The report is part of the Nordic Prime Ministers' overall green growth initiative: "The Nordic Region - leading in green growth". Read more in the web magazine "Green Growth the Nordic Way" at www.nordicway.org or at www.norden.org/ greengrowth 